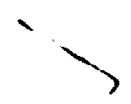

\title{
Resin-Based Preparation of HTGR Fuels: Operatien of an Engineering-Scale Uranium Loading System
}

P. A. Haas 
Contract No. W-7405-eng-26

CHEMTCAI TECHNOLOGY DIVTSTON

THORIUE UTILIZATION PROGRAM

Refabrication Development - Task 300

RLSIN-BASED PREPARATION OF HTGR FUELS: OPERATION OF AN ENGINEERING-SCALE URANIUM LOADING SYSTEM

P. A. Haas

Date Published: Octoher 1977

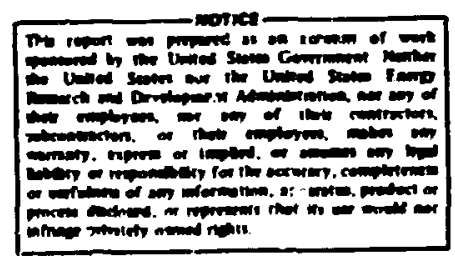

OAK RIDGE NATIONAL LABORATORY

Oak Ridge, T?nnessee 37830

operated by

UNION CARBIDE CORPORATION

for the

ENERGY RESEARCH AND DEVELOPMENT ADMINISTRATION 
conrrarrs

Page

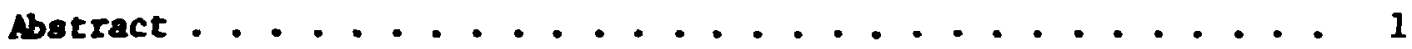

1. Introduction .................. 1

1.1 scope ...................... 2

1.2 Acknowledgments ................ 4

2. Description of the Process .............. 4

2.1 Chentcal Flowsheet ............... 6

2.1.1 Resin loading reactions ........... 6

2.1.2 Properties of ADU solutions . . . . . . 12

2.1.3 Nitrate extraction reactions ......... 14

2.1 .4 Composition of the resin ......... is

2.2 Product Specifications . . . . . . . . . 17

3. Resin Loading ................. 19

3.1 Batch vs Continuous Resin Loading . . . . . . . 21

3.2 Batch Resin Loading Contactor............ 22

3.3 Continuous (H1gg1ns) Resin Loading ........ 25

4. Drying of Uranium-Loaded Resin ............. 25

4.1 Capacity .................... 26

4.2 Specifications for Dried Product . . . . . . . 27

4.3 Description of the Mfcrowave Dryer ......... 28

4.4 Results Obtained by Microwave Drying ........ 32

5. Evaporator .................... 33

6. Nitrate Extraction ................... 35,

6.1 N1trate Extraction Equipment ........... 37

6.2 Phase Separation and Interface rontrol .......40 


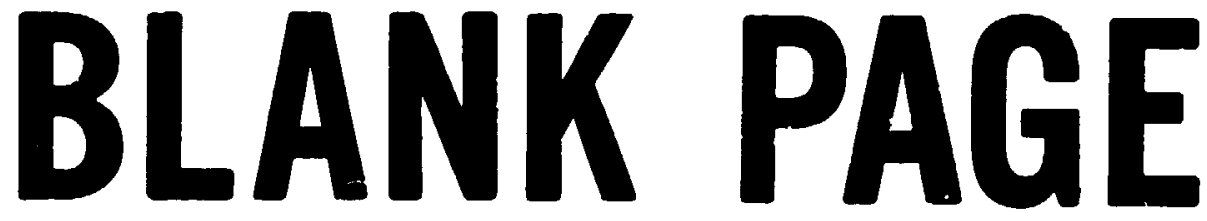


COATENTS

PAGE

6.3 Equipment Perismance ............... 45

6.4 Partial Regeneration of Amine ............. 46

6.5 Uranium Losses .................... 47

7. Overall Process Behavior and Control ............ 48

7.1 Uranium Inveitory ................. 51

7.2 Water Inventory ................. 53

7.3 Mtrate Inventory . . . . . . . . . . . . 54

7.4 In-1ine pH Units to Keasure $\mathrm{NO}_{3}{ }^{-} / \mathrm{U}$ Ratios ........ 55

7.5 Experimental Results ............... 57

7.6 End-of-Campaign Loading Procedures and Regults . . . . 66

8. Effects of Feed Resin Variables ............. 67

9. Mechanical Components, Resin Transfers, and Equipment

Selection ...................... 68

9.1 Pumps and Liquid Metering . . . . . . . . . . 68

9.2 Temperature Control ................ 69

9.3 Resin Transfers .................. 69

10. Discussion and Concluslons . . . . . . . . . . . . 71

11. References ...................... . 73

12. Appendixes . . . . . . . . . . . . . . 75 
RESIN-BASED PREPARATION JE HTGR FUELS: OPERATION OF AI ERGINEERING-SCALE URANIUM LOADING SYSTEM

P. A. Haas

\begin{abstract}
The fuel particiess for recycle of ${ }^{233} \mathrm{U}$ to High-Temperature Gas-Cooled P.eactora dre prepared from uranium-loaded carboxylic acid ton exchange resins which are subsequently carbonized, converted, and refabricated. The development and operation of individual items of equipment and of an integrated system are descrited for the resin-loading part of the process. This engineering-scale system was full scale with respect to a hnt demonstration facility, but was operated with natural uranfum. The feed uranium, which corsisted of uranyi nitrate solution containing excess nitric acid, was loaded by exchange with resin in the hydrogen form. In order to obtain high loadings, the uranyl nitrate must be acid deficient; therefore, nitric acid was extracted by a liquid organic amine which was regeneiated to discharge a $\mathrm{NaNO}_{3}$ or $\mathrm{NH}_{4} \mathrm{NO}_{3}$ solution waste. Water was removed from the uranyl nitrate solution by an evaporator that ylelded condensate containing less than 0.5 ppa of uranium. The uranium-loaded resin was washed with condensate and dried to a controlled water content via microwave heating. The loading process was controlled via inline measurements of the $\mathrm{pH}$ and density of the uranyl nitrate. The demonstrated capacity was $1 \mathrm{~kg}$ of uranium per hour for elther bazch loading contactors nr a continuous column as the resin loac'ing contactor. Fifty-four batch loading runs were made without a single fallure of the process ourlined in the chemical flimisheet or any evidence of inability to control the conditions dictated by the flowsheet.
\end{abstract}

\title{
1. INTRODUCTION
}

The reference fuel kernel for recycle of ${ }^{233} \mathrm{U}$ co High-Temperature GasCooled Reactore (HTGRs) is prepared by loading carboxylic acid cation exchange resins with uranium and carbonizing at controlled conditions. The carbonized products must be spheres containing high uranium concentrations and only cartion and oxygen as the other major constituencs. 
A process that would give acceptable loaded spheres vas initialy developed using the hydrogen form of the cation resin and $\mathrm{UO}_{3}$ to maintain acid-deficient uranyl nitrate. ${ }^{1,2}$ The purified $233_{\mathrm{UO}_{2}}\left(\mathrm{NO}_{3}\right)_{2}$ solution froa a fuel reprocessing plant contulns excess nitric acid $\left(\mathrm{NO}_{3}{ }^{-} / \mathrm{U}\right.$ ratio 2.2). When the requiresents for renote operation, accountability, and control of nuclear criticallty were considered, the usual processes for preparing $\mathrm{VO}_{3}$ and the $\mathrm{In-cell}$ use of $\mathrm{UO}_{3}$ did not seen acceptable. Therefore, en ine extraction process was developed for resin loading.

The reference flowsheet for a ${ }^{233}$ v recycle fuel facilfty at Oak RIdge National Laboratory uses solvent extraction of nitrate by a $0.4 \underline{M}$ secondary amine in a hydrocarbon diluent to prepare actd-deficient uranyl nitrate (ADUN) solutions. This nitrate extraction, along with the resin loading and amine regeneration steps, was demonstrated in 14 runs $^{3}$ utilizing components and procedures developed in previous sol-gel studies. Conditions expected to be satisfactory were used without any systematic optimization of variables. The engineering-scale resin loading system described here was the next stage of the development program followng the process demonstration studies, ${ }^{3}$ but prior to the design of a remotely operated p1lot plant.

\subsection{Scope}

It was considered necessary to obtain results from the operation of a complete, integrated resin loading system prior to designing a fuel recycle facility for HTGR fuels. The recycle of ${ }^{233} \mathrm{U}$ imposes certain requirements relative to remole operation, control of criticality, treatment of wastes, and material accountabjifty which do not apply to the 
process demonstration with natural uranium. The engineering-scale resin loading system was intended to provide information on concepts recessary to meet these requirements; however the engineering-scale system did not neet such requirements in detall and was limited to natural uranium.

The engineering-scale resin loading system is full scale with respect to the proposed fuel recycle pilot plant. The capacity of the recycle pilot plant is one batch per day, with $4 \mathrm{~kg}$ of ${ }^{233} \mathrm{U}$ per batch. The Individual process operations were intended to be much shorter, ith a maximum of 4 to $6 \mathrm{hr}$ per batch. This aliows sequential operations with a minimum number of personnel in the pilot plant. It also means that scale-up to a commercial recycle plant capacity of about $25 \mathrm{~kg}$ of ${ }^{233} \mathrm{u}$ per day would not require any increase in equipment size. Alternate operation of two batch loading contactors would give $24 \mathrm{~kg}$ of ${ }^{233} \mathrm{v}$ per day (six 4-kg batches using a nitrate extraction system, an evaporator, and a resin dryer of the same sizes as the engineering-scale units).

This report on the engineering-scale resin loading system will present results for the complete system and w11 provide detalls on individual processes or operations only when they are not reported elsewhere. The design, fabrication, and testing of the microwave dryer for uraniumloaded resin and of the evaporator for the ADUN have been reported separately in detall. The cocurrent contactors useu in the amine regeneration system were designed, fabricated, and described as part of the sol-gel development. Laboratory studies of the equilibrium and kinetics of the resin loading reactions are being reported by Shaffer et al. ${ }^{4}$ 


\subsection{Acknowledgments}

The operation of the engineering-scale resin loading system was part of the Thoriun Jtilization Prograa and was dependent on Interactions with, or contributions fros, many individuals assigned to this program. Arong these were: R. J. Notz (Progran Director for the Cheatcal Technology Division;; J. H. Shaffer (chenical flowsheet studies); J. P. Drago, D. L. Hilion, and R. D. Spence (equipment developwent); and R. D. Arthur, T. V. Dinsecre, and J. R. Parrott, Jr. (systen opiration). R. D. Arthur supervised the inftial installation of equipuent. The drfed, uraniumload. :esin was used and evaluated by W. J. Lackéy, ?. A. Carpenter, Jr., and others of the Metals and Ceramics Division.

\section{DESCRIPTION OF THE PROCESS}

The purtfied ${ }^{233} \mathrm{UO}_{2}\left(\mathrm{NO}_{3}\right)_{2}$ feed from a fuel reprocessing plant contains excess aitric actl $\left(\mathrm{NO}_{3}{ }^{-} / \mathrm{U}\right.$ ratio $\psi_{2.2)}$ and introduces urantum, nitrate, and water to the resin losding system. The cation exchange resin is fed as a slurry of acid-(hydrogen-) form resin spheres in water. The uranium leaves the resin loading system as the dried uranium-form resin. Exces 3 water 18 removed from the uranyl nitrate as condensate from an evaporator. The nitrate extraction system uses a regeneration by caust1c solution (NaOH, $\mathrm{NH}_{4} \mathrm{NH}$, ur $\mathrm{Na}_{2} \mathrm{CO}_{3}$ - $\mathrm{NaOH}$ ) to discharge nitrate as $\mathrm{NaNO}_{3}$ or $\mathrm{NH}_{4} \mathrm{NO}_{3}$ waste solution. These operations can be integrated (F18. 1) into an efflclent system for converaion of the uranyl nitrate solution into loaded, dried reain.

The uranyl nitrate feed, Including the excegs nitric acid, is introduced into a central surge tank (F1g. 1). One stream of solution 18 pumped 


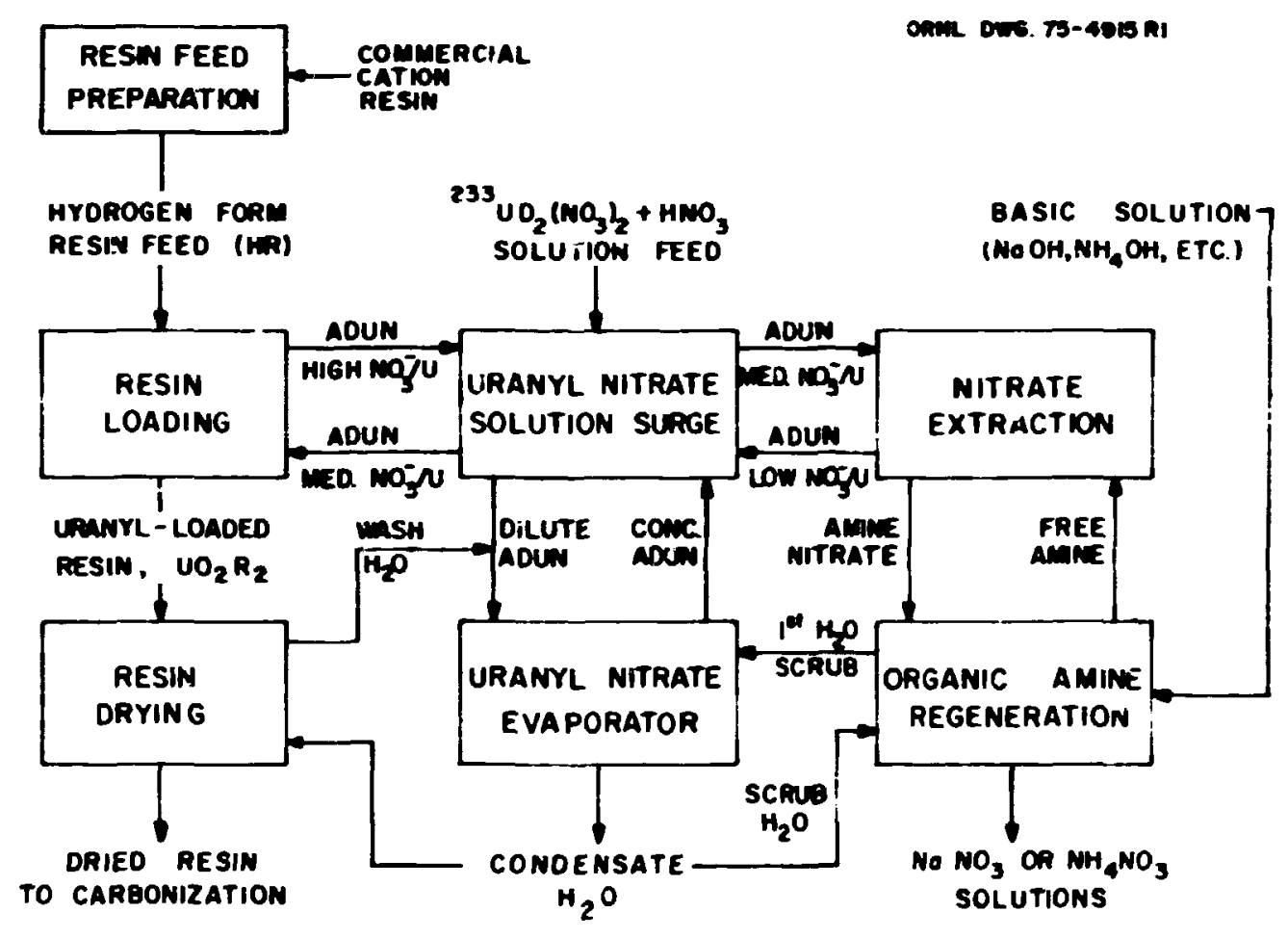

"ADUN" INDICATES ACID-DEFICIENT URANYL NITRATE (NO 3 /U<2, MOLES/MOLE)

Fig. 1. Schematic reference flowsheet fo- uranium loading of resin. 
to a resin loading operation where part of the uranium is rewoved by exchange with the resin and a less acid-deficlent uranyl nitrate returns. Another strean is pumped to the evaporator where sone of the water is removed and a concentrated stream returns. A third streas is pumped to a nitrate extiaction system and returns with a reduced nitrate concentration. The engineering-scale resin loading systen is concerned with integrated, simultaneous operation of the processes shown in Fig. I.

\subsection{Chemical Flowsheet}

From the usual concepts for lonlc solutions, uranyl nitrate would be expected to give $\mathrm{UO}_{2}{ }^{2+}, \mathrm{UO}_{2}\left(\mathrm{NO}_{3}\right)^{+}$, and $\mathrm{NO}_{3}^{-}$Ions. However, the conditions used for our resin losding process result in complex hydrolytic behavior of the uranium. Among the specles that have been proposed are: $\mathrm{U}_{2} \mathrm{O}_{5}{ }^{2+}$ or $\mathrm{UO}_{2}\left(\mathrm{UO}_{3}\right)^{2+}, \mathrm{U}_{3} \mathrm{O}_{8}{ }^{2+}, \mathrm{U}_{3} \mathrm{O}_{8}(\mathrm{OH})^{+}, \mathrm{UO}_{2}(\mathrm{OH})^{+}$, ar $\mathrm{UO}_{2}\left[(\mathrm{OH})_{2} \mathrm{LO}_{2}\right]_{\mathrm{n}}{ }^{2+} \cdot \mathrm{High}$ anion concentrations can result in negatively charged complexes of uranium of the type $\mathrm{UO}_{2}\left(\mathrm{NO}_{3}\right)_{4}{ }^{2-}$. The existence of these complex spectes will be ignored during our discussion of the chemical reactions for resin lading and nitrate extraction. The simple reactions correctly glve the overall net effect; however, atcempts to use them to correlate the equilibrium and kinetlc behavior w11 give anomalous results.

\subsubsection{Resin laading reactions}

The net effect of resin loading is to exchange one uzanyl ion for two hydrogen lons. When the carboxylic acid resin equivalent to one exchange site is indicated by $R$, the net exchange reaction is:

$$
\mathrm{UO}_{2}^{2+}+2 \mathrm{HR}+\mathrm{UO}_{2} \mathrm{R}_{2}+2 \mathrm{H}^{+} \text {. }
$$


Although it is useful to discuss the concentrations and wite an equilibrium constant as if this were a simple chemical reaction, the inaccuracies of this approach should be recognized. The uraniun in solution is hydrolyzed or othervise complexed and is only parily present as $\mathrm{UO}_{2}{ }^{2+}$. The resin is a porous solid, and activities and volume concentrations are either very difficult to neasure or of doubtful significance.

The exchange of $\mathrm{UO}_{2}{ }^{2+}$ for $\mathrm{H}^{+}$in the feed resin is limited by the back-reaction as $\mathrm{H}^{+}$accumlates in the solution. The accumation of $\mathrm{H}^{+}$ can be controlled by using a salt form of the resin or adding base to the solution. Amontum ton is mostly volatilized (as amonia) when the resin is carbonized, whice metals generally remain as unacceptable impurities in the final product. For the originai cevelopment of $\mathrm{UO}_{2}{ }^{2+}$-loaded carboxylic acid resins, the $\mathrm{H}^{+}$concentration was controlled by reaction with $\mathrm{UO}_{3}$ as follows: 1,2

$$
2 \mathrm{H}^{+}+\mathrm{UO}_{3} \rightarrow \mathrm{UO}_{2}^{2+}+\mathrm{H}_{2} \mathrm{O}
$$

The purified ${ }^{233} \mathrm{U}$ from a fuel reprocessing plant would be uranyl nitrate containing some excess nitric acid. The preferred procedure for using uranyl nitrate solution feed is to remove nitric acid from the solution and thus control the $\mathrm{H}^{+}$concentration according to the following reaction:

$$
\mathrm{H}^{+}+\mathrm{NO}_{3}^{-} \rightarrow \mathrm{HNO}_{3}
$$

The reference process for resin loading, and the process used in the engineering-scale system, is to extrace nitric acid with a liquid organic amine (see Sect. 2.1.3). 
While stoichivetric uranyl nitrate has $\mathrm{NO}_{3}^{-}$th mole ratio of 2.0 , nitric acid can be extracted from uranyl nitrate solutions to give ratios as 10 as 1.5 without precipitation of urantum. The same low ratios can be obtained by dissolving $\mathrm{UO}_{3}$ according to Eq. (2). These solutions are comenly called ADU, and the average composition for a $\mathrm{NO}_{3}^{-} \mathrm{NO}$ rat 10 of 1.5 would be $\mathrm{VO}_{2}(\mathrm{OH})_{0.5}\left(\mathrm{NO}_{3}\right)_{1.5^{\circ}}$ Stolct lometric uranyl nitrate will only allow about $80 \mathrm{Z}$ exchange of $\mathrm{VO}_{2}{ }^{2+}$ for $\mathrm{H}^{+}$. while ADUN Is necessary for the high (295\%) conversions required for resin-based fuel preparation.

The equilibrium daca for the exchange of $\cdot \mathrm{UO}_{2}{ }^{2+}$ for $\mathrm{H}^{+}$have been Investigated experimentally and correlated by Shaffer et al. 4 The results are presented as equilibrium quotients for $\mathrm{Eq}$. (1), wth the temperature and the resin type as parameters. As a result of the complex uranyl spectes in solution, the equilibrium quotients are also functions of the nitrate ion concentrations. The typical result is show for conditims near those most comonly used in our engineering-scale system runs (FIg. 2 ). The $\mathrm{H}^{+}$concentrations are calculated from $\mathrm{pH}$ measurements, and the resin concentrations are given in moles per liter of wet resin.

Process control for the engineering-scale system is malntalned through In-line measurements of ADUN pH. Shaffer's data can also be presented as the resin loading (that 18 , the percent exchange of $\mathrm{VO}_{2}{ }^{2+}$ for $\mathrm{H}^{+}$) $\mathrm{V} 8 \mathrm{ADUN}$ PH with $\mathrm{NO}_{3}^{-}$concentration as a parameter (F1g. 3). The data of Shaffer et al. for pH ve percent loading can be combined with data for the ADUN solution (see Sect. 2.1.2) to give $\mathrm{NO}_{3}{ }^{-} / \mathrm{U}$ ratios v8 percent resin laeding (i18. 4). For $0.2,0.6$, and $1.0 \mathrm{~N} \mathrm{NO}_{3}{ }^{-}$, there was no significant difference between the Amberlite IRC-72 and Duolite $\mathrm{C}-464^{\text {t* }}$ resins or the temperatures *Trademark of the Rohm and Heas Co.
*t Trademark of ths Dlemond Shamrock Co. 
OANL DWB T6-986 RI

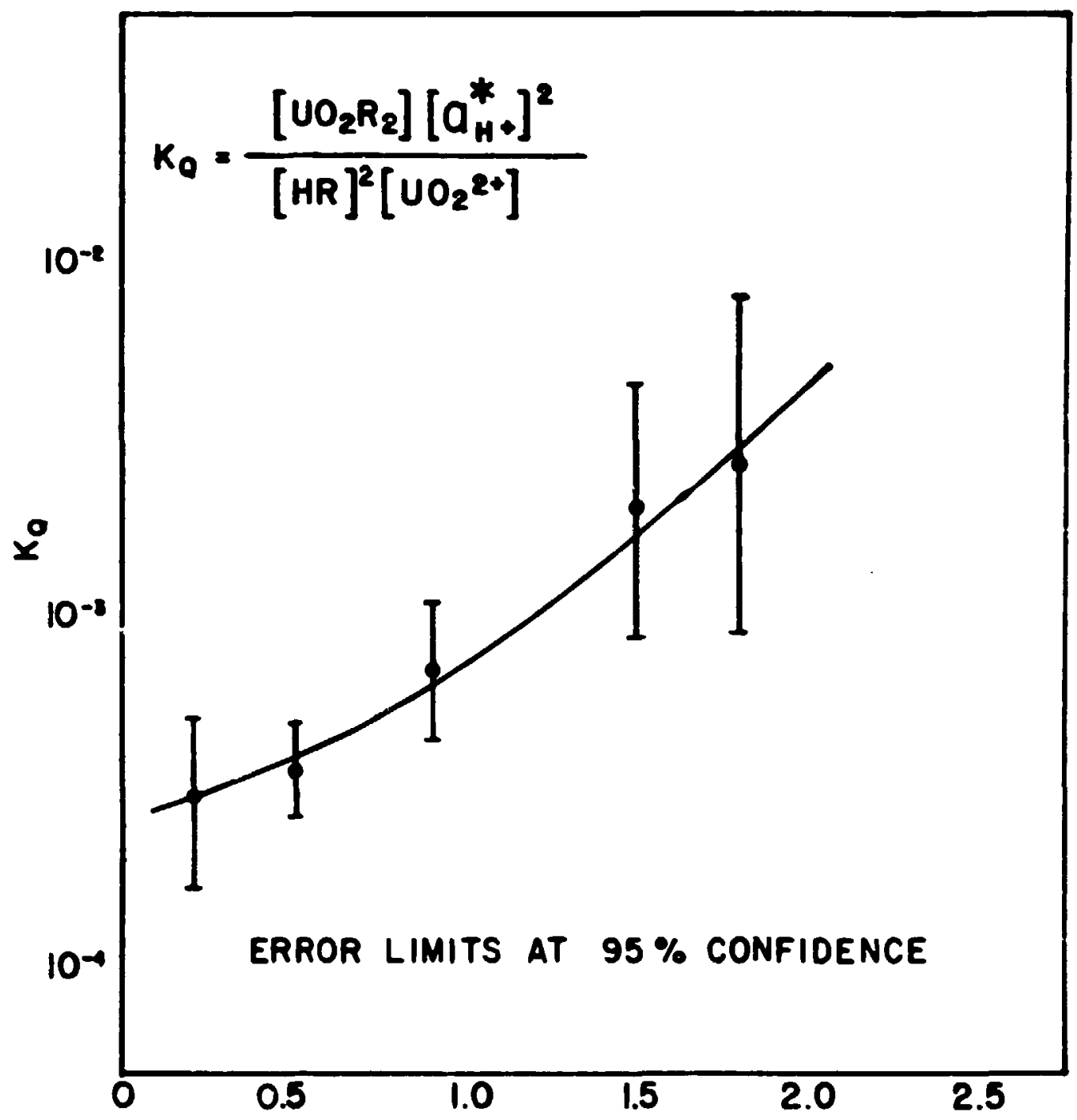

Fig. 2. Equilibrium quotient for uranium loading vs nitrate concentraition (Amberlite IRC-72 at $40^{\circ} \mathrm{C}$ ). (See ref. 4.) 


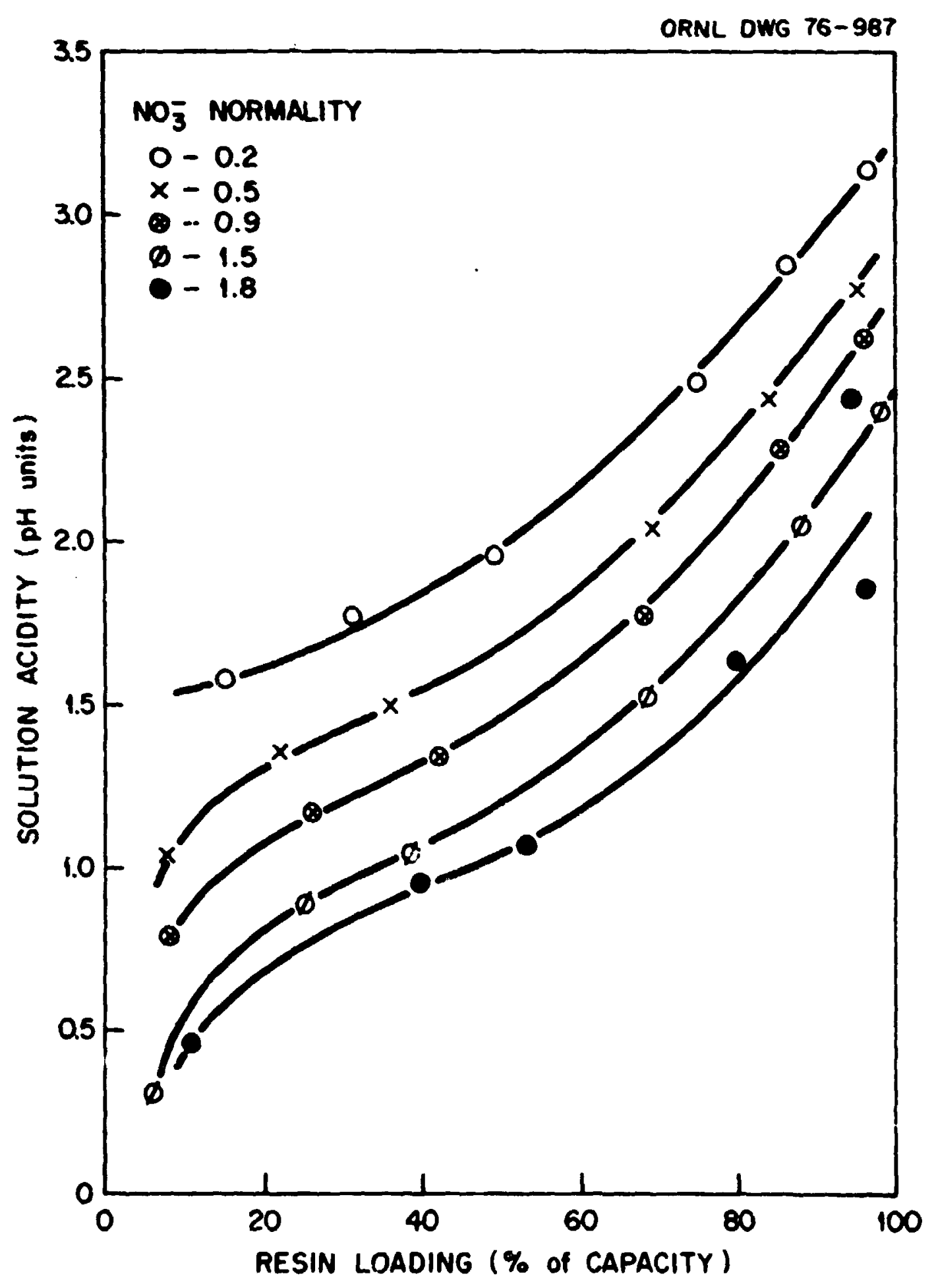

F1g. 3. Equilibrium loading of urantum vs solution pll (Amberitte IRC-72 at $4,{ }^{\circ} \mathrm{C}$ ). (See ref. 4. ) 


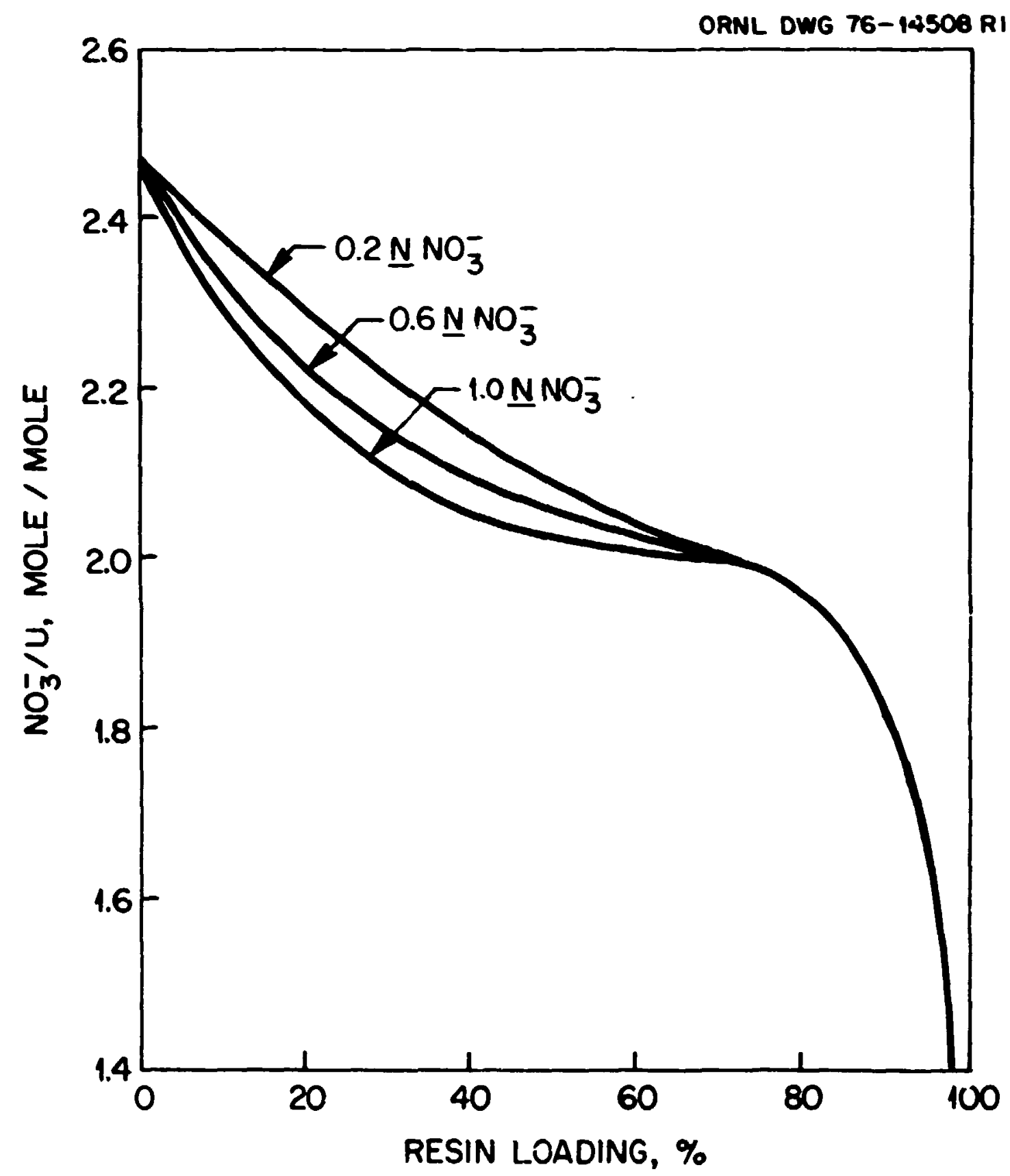

Fig. 4. Equilibrium loading of uranium vs solution $\mathrm{NO}_{3}^{-} / \mathrm{U}$ zatio (Amberlite IRC-72 or Duolite C -464 at 30 or $40^{\circ} \mathrm{C}$ ). 
of $30^{\circ} \mathrm{C}$ and $40^{\circ} \mathrm{C}$. For the controlling region of above $70 \%$ loading, all the conditions of Inportance to the engineering-scalt resin loading are represented by a single curve of percent loading vs $\mathrm{NO}_{3}^{-} \mathrm{T}$ ratio. This is an infortant simpliftcation for the purpose of making calculations.

\subsubsection{Properties of ADUN solutions}

The densities, pHs, and conductivities of ADUN solutions were weasured experimentall $\because$ and correlated by Botts with uranium concentration, $\mathrm{NO}_{3}{ }^{-} / \mathrm{U}$ ratio, and temperature as variables. 5 The ranges of interest to the englneering-gcale resin loading are less than $0.5 \underline{H}$ uraniu, 25 to $50^{\circ} \mathrm{C}$, and $\mathrm{NO}_{3}{ }^{-} / \mathrm{U}$ ratics of 1.5 to 1.9 . For thls range, the density data are adequately represented by:

$$
\begin{aligned}
\rho(\text { ADUN }) & =\rho\left(\mathrm{H}_{2} \mathrm{O}\right)+0.324[\mathrm{U}], \\
{[U] } & =3.10\left[\rho(\text { ADUN })-\rho\left(\mathrm{H}_{2} \mathrm{O}\right)\right],
\end{aligned}
$$

where

$$
\begin{aligned}
& \rho(A D U N)=\text { density of ADUN, } 8 / \mathrm{cm}^{3} ; \\
& \rho\left(H_{2} O\right)=\text { density of } H_{2} O \text { at the same temperature; } \\
& {[U]=\text { uranium mclarity. }}
\end{aligned}
$$

The experimental measurements of Botts ${ }^{5}$ for $\mathrm{pH}$ at $56^{\circ} \mathrm{C}$ are show with a log scale for uranium molarity (Fig. 5) to facilitate incerpolation at the lower uranium concentrations. For the acid-def 1 c:ient concentrations $\left(\mathrm{NO}_{3}{ }^{-} / \mathrm{U}\right.$ rat1o $\left.<2\right)$, the reported $\mathrm{pH}$ values averaged 0.22 unit higher at $25^{\circ} \mathrm{C}$ and 0.22 untt lover at $75^{\circ} \mathrm{C}$ as compared with the values at $50^{\circ} \mathrm{C}$. As a result of the uranium complexes present, attainment of an equilibrium pH requires a long time compared with that for simple lonic solutions. 


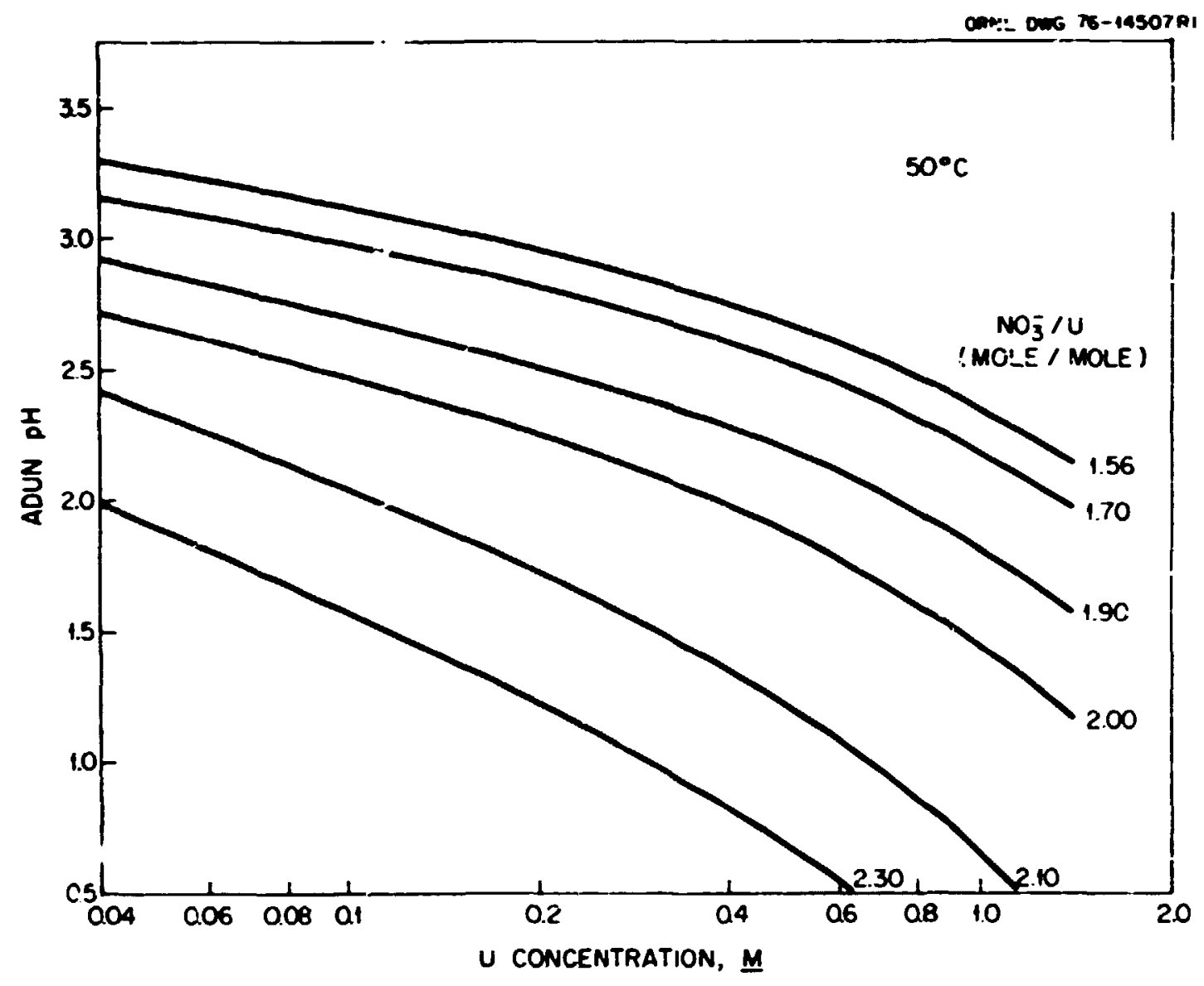
$\mathrm{NO}_{3}^{-}$ratio. 
Samples removed from the engineering-scale system frequently show rapid pH changes for several minutes and small, slow changes for much longer times. The conductivity of the ADUN is very dependent on t' sperature, uranium concentration, and $\mathrm{NO}_{3}^{-} / 0$ ratio. The equations given by Botts would allow the conductivity measurement to be used for computer control of a resin loading process, but the density and $\mathrm{pH}$ give the two Important concentrations $\left[\mathrm{U}\right.$ and $\left.\mathrm{NO}_{3}{ }^{-} / \mathrm{U}\right]$ more convenient ly and directly fram Eq. (4b) and Fig. 5 .

\subsubsection{Nitrate extraction reactions}

Equations of importance to the nitrate extraction system include the following, where $X_{2}$ MH represents the Amberlite LA-2* secondary amine (N-laury l-N-trlalkylmethylamine):

$$
\begin{gathered}
\mathrm{X}_{2} \mathrm{NH}+\mathrm{HNO}_{3} \rightarrow \mathrm{X}_{2} \mathrm{NH}_{2} \mathrm{NO}_{3} \\
\mathrm{X}_{2} \mathrm{NH}_{2} \mathrm{NO}_{3}+\mathrm{NaOH} \rightarrow \mathrm{X}_{2} \mathrm{NH}+\mathrm{NaNO}_{3}+\mathrm{H}_{2} \mathrm{O} \\
\mathrm{X}_{2} \mathrm{NH}_{2} \mathrm{NO}_{3}+\mathrm{Na}_{2} \mathrm{CO}_{3} \rightarrow \mathrm{X}_{2} \mathrm{NH}+\mathrm{NaNO}_{3}+\mathrm{NaHCO}_{3} \\
\mathrm{X}_{2} \mathrm{NH}_{2} \mathrm{NO}_{3}+\mathrm{NH}_{4} \mathrm{OH} \rightarrow \mathrm{X}_{2} \mathrm{NH}+\mathrm{NH}_{4} \mathrm{NO}_{3}+\mathrm{H}_{2} \mathrm{O} \\
2 \mathrm{X}_{2} \mathrm{NH}+2 \mathrm{H}^{+}+\mathrm{UO}_{2}\left(\mathrm{NO}_{3}\right)_{4}^{2-}+\left(\mathrm{X}_{2} \mathrm{NH}_{2}\right)_{2} \mathrm{NO}_{2}\left(\mathrm{NO}_{3}\right)_{4}
\end{gathered}
$$

Both the reaction for nitrate extraction, Eq. (5), and the reactions for regeneration Eqs. (6) $-(8)$, are very favorable chemlcally and can be forced to completion with essentially $100 \%$ utilization of one of the reactants. Since excessive extraction of $\mathrm{HNO}_{3}$ will precipitate uranium in the ADUN solution, the nitrate extraction contactor is always supplied with a large excess of A.DUN. One theoretical stage of contact would provide complete converstion of the amine to the nitrate salt form. Although Trademark of the Rohm and Haas Co. 
the spray colum used for the nitrate extraction contactor is not designated for high efficiency, it results in greater than 993 conversion.

The conditions in the regeneration confactor are selected to improve phase separation. Phase separation is poor at high pH values with stable ewulsions being formed in the presence of large excesses of NaOH. In the first demonstration of this resin loading process, ${ }^{3}$ the amine was completely regenerated by using an excess of base. Use of an excess of NaOH was not practical in the engineering-scale system because of the emulsion problem; therefore, the regeneration was carried out with equiwolar mixtures of $\mathrm{NaOH}$ and $\mathrm{Na}_{2} \mathrm{CO}_{3}$. Partial regeneration of the amine using an excess of anine nitrate has important advantages, and the results are reported in Sect. 6 .

The uranium in uranyl solutions can form negatively charged complexes which can react with the amine. Equation (9) is included to illustrate this type of reaction but does not mean that a romplex of the formula Indicated was known to be present. Any uranium complexes which reach the amine regeneration contactor result in losses of uranium to the aqueous waste. Thus, high urantum concentrations or high $\mathrm{NO}_{3}^{-} / \mathrm{U}$ ratios in the ADUN are undesirable since they javor the formation of such complexes. Aqueous scribs of the amine nitrate can be used to recover both uranium complexes and entrained ADUN before they reach the amine regeneration contactor.

\subsubsection{Composition of the resin}

The composition of the dried, $\mathrm{UO}_{2}{ }^{2+}$-loaded resin depends on the average formula of the feed resin, the extent of loading, the drying 
conditions, and the presence of impurities. Both Amberlite IRC-72 and Duclite C-464 are prepared by polyerizing acrylic acid with divinylbenzene (DJB) to provide cross-linkage and thereby Inprove the physical properties of the resin. Amberlite IRC-72 is manufactured to contain 10 wt $7 \mathrm{DVB}$, Which is supplied as a comercial nixture containing a saller anount of ethylvingibenzene (EVB) and slight anounts of other constituents. The resulting resin polyner thus contains 10 wt $Z$ DVB plus varying anounts of EVB, depending on the atxture; the balance is relatively pure acrylic acid (molecular welght, 72.064). The active group for cation exchange is the carboxylic acid (-coot), and capacities or "equivalent veights" are for equivalents of carboxylic acid.

The composition of one batch of Amberlfte IRC-72 in the hydrogen form Is equivalent to the following: $\$ 3.000$ wt $7 \mathrm{DVB}, 7.982$ wt $Z \mathrm{EVB}$, and 82.018 we $Z$ acryllc acid. The equivalent weight is then $72.064 / 0.82018$, or 87.86 8. The calculated cation exchange capacity (CEC) in millequivalents per gram (neq/g) of dry, hydrogen-form resin is $1000 / 87.86$, or 11.38 . Complete cation exchange results in $86.86 \mathrm{~g}$ of resin combining wth 1 equiv of the cation that replaces the hydrogen.

The measured CEC values for Amberlite IRC-72 vere generaliy 10.3 to 10.7 meq per gram of $\mathrm{dry}, \mathrm{H}^{+}$-form resin. The uranius-loaded carboxyl1e acid resins contaln uranium, carbon, hydrogen, and oxygen as the only major constituents. Spectrochemical analyses shor about 300 ppm (based on uranium) of total metallic impurities. The standard uranium and carbon analyses are accurate and relatively simple, while oxygen and hydrogen are more troublesome. Analyses of two uranium-loaded Amberlite IRC-72 samples mere: 


\begin{tabular}{llll}
$\begin{array}{c}\text { Ana lysis } \\
\text { (8/8 dry resin) }\end{array}$ & Sample 1 & Sample 2 \\
\cline { 1 - 1 } Uranium & 0.4656 & 0.481 \\
Carbon & 0.2340 & 0.2216 \\
Hydrogen & 0.0335 & 0.0372
\end{tabular}

The loaded resin has carbon/uranium mole ratios of about 9 , in agreement wth about 957 exchange of uranyl fon for hydrogen. Other analyses indicate abcut 2 moles of water per mole of uranium at the standard Loss on Drying (LOD) conditions of $110^{\circ} \mathrm{C}$. The hydrogen- and sodium-form resins do not retain water at these LOD conditions; the water with the uranylloaded resin is probably bound with the cation as $\mathrm{U}\left(\mathrm{OH}_{4}\right)_{4}{ }^{2+}, \mathrm{UO}_{2}\left(\mathrm{H}_{2} \mathrm{O}\right)_{2}{ }^{2+}$, or some simflar structure. The average structure per uranium atom migit be represented by $\mathrm{UO}_{2}\left(\mathrm{H}_{2} \mathrm{O}_{2}{ }_{2}^{\mathrm{H}} 0.1^{\left(\mathrm{C}_{4.6} \mathrm{H}_{4.7} \mathrm{O}_{2}\right)_{2.1}}\right.$.

\subsection{Product Specifications}

In general, the primary product specifications are those for the carbonized and/or coated kernels; in addition, the dried, urantum-loaded resin must be suitable for carbonization, conversion, and coating to meet those primary specifications. Secondary specifications for resin loading have not been written. The size, shape, sphericity, and some impurities are determined and controlled by resin feed preparation. The specifications of greatest importance to the loading of the resin require the following:

1. A high uranium content; that $1 \mathrm{~s}$, nearly complete exchange of $\mathrm{jO}_{2}{ }^{2+}$ for $\mathrm{H}^{+}$in the resin exchange sites. For gome fuel loadings, the usual uranium content of resin-based kernels is just adequate; that is, lower uranium contents would require other preferred conditions to be compromised. 
2. Reproductbility of a spectfied loading to required to weet specifications for chenical composition, uxanium content, and uniformity. The range of allowable chentcal compositions is not very restrictive, and varlations in loading would probably componise the uranius content or the uniforatiy of loading before the chenical couposition falled to neet specifications.

3. Unfforaity of uranion loading from particle to particle. The effects of nonuniformity have not been determined. A high degree of uniformity is preferred since determination of the allawable extent of nonuniformity would require a major experinental program.

4. Uniformity within a particle. Nonuniforaity could result from variations in resin capacity that occur because of volds or shell structure, or from nonuniform loading of uranium due to mass transfer effects. The coments for (3) also apply to this item.

5. No material should be added that would distribute impurities to the carbonized kernels or that would result in uncontrolled variations in carbon and oxygen contents after carbonization. Both the neutron cross sections and the chemical effects during refabrication and Irradiation are Important in considering the effects of impurities.

6. The shape of the kernels must not be degraded by cracking, clustering, or other changes.

7. The average uranium content of one fuel kernel should be about $65 \times 10^{-6} \mathrm{~B}$. 
The general appraach for the first five items has been to develop a practical resin laading process and then determine whether the products are acceptable. The final secondary specifications would then require products known to be acceptable rather than determination of the minimum acceptable specifications. Irradiation tests are currently in progress to provide information for a minimum acceptable shape specification (1tex 6).

\section{RESIN LOADING}

During the resin loading step, uranyl ion is exchanged for hydrogen Ions as represented by Eq. (1). This cation exchange process is controlled by the reactions, kinetics, and equllibria discussed in the previous section. The resin discharged fran the lading contactor must meet the product specifications, and the uranium loading rates must be compatible with satisfactory operation of the remainder of the system.

The resin loading method for preparing HTGR fuel differs from the more common ton exchange processes in a digtinct and significant way. Here the resin is the product, whereas the solution is the product in most ion exchange processes. As a result, all of the resin must be uniformly loaded. The solution, on the other hand, is recycled, and a large excess or poor utilization of it 18 of little importance. Charging and discharging the resin are part of the routine operation and must be done without significant residues or losses. Higure 6 shows a diagram of the uranium and resin f lows. 
ORNL DWG 76-926 RI

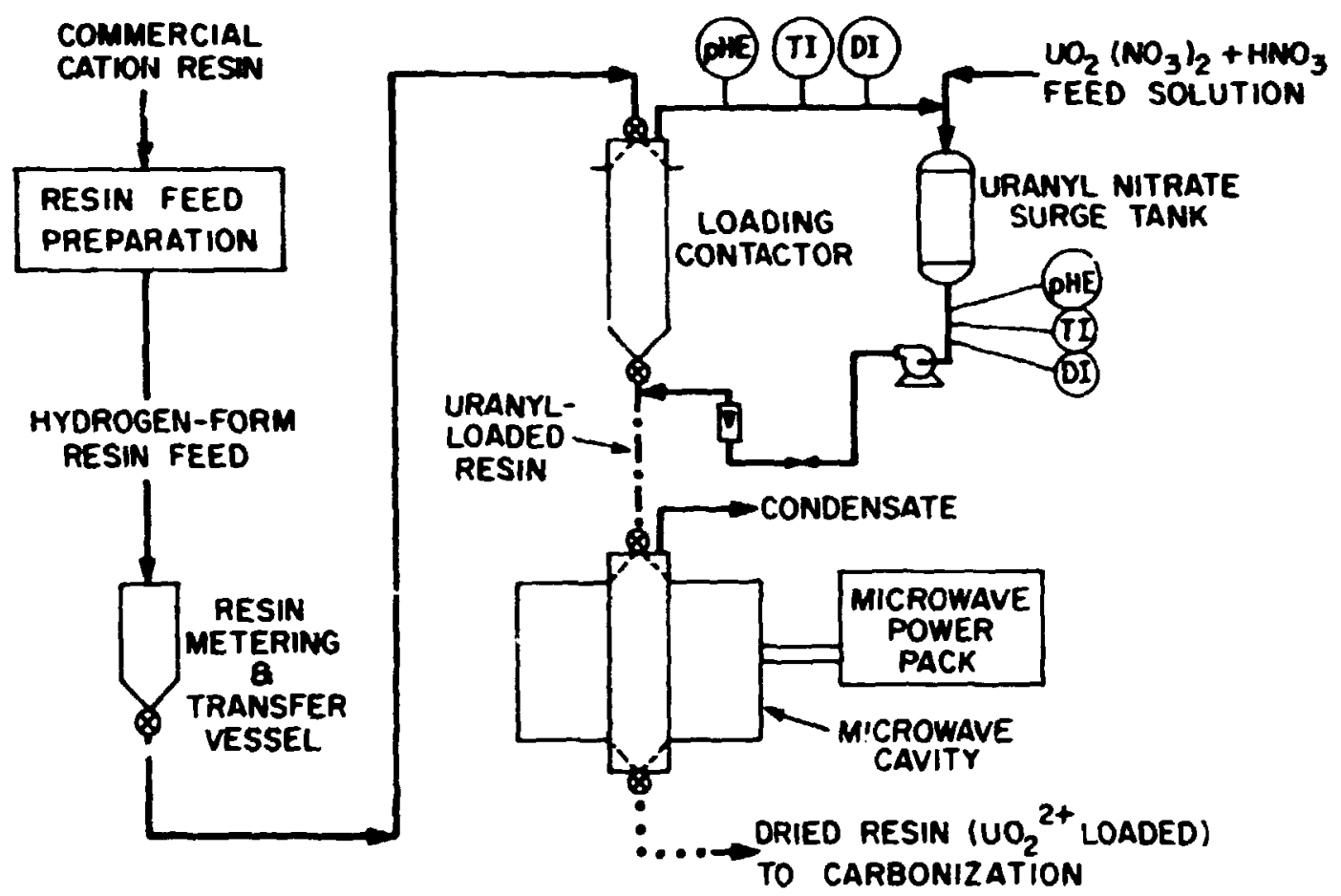
loading.

P1g. 6. Process flows of uranium and Ion exchange resin for resin 


\subsection{Batch vs Jontinuous Resin La.lding}

warbonization and conversion of the uranium-loaded resin nust je carried out batchwise in order to provide a complex sequence of process

conditions, ${ }^{6}$ and the anount of aterial in each process is dictated by nuclear criticality linitations. The dally capacity of a recycle fuel pllot plant or saall comercial plant is equivalent to 1 to $10 \mathrm{~g}$ of uranium per minute; such quantities are too snall for efficient continuous operation. Therefore, the erigineering-scale resin loading was developed for batch loading with $4 \mathrm{~kg}$ of uranium ;er batch.

The process operations associated with the extraction of nitric acid are most conveniently done in a continuous mode. The volumes or amounts of solvent, ADUN solution, and uranium are excessive for batch nitrate extraction with a loading of $4 \mathrm{~kg}$ of uranium per batch. Therefore, a continuous nitrate extraction system was combined with a batch resin loading contactor. A nitrate extraction capacity equivalent to the loading of $1 \mathrm{~kg}$ of uranium per hour was conventent for several reasons. A 4-hr loading time allows a convenient schedule of batch operations and easily meets the minimum kinetic requirements for full loading. Smaller capacities would not result in any significant reductions in the cost or space requirements for the nitrate extraction system. Finally, the 1-kg-ofuranium-per-hour capacity for nitrate extraction could be increased to $24 \mathrm{~kg} /$ day if two batch loading contactors were used alternately to achleve continuous operation. The engineering-scale resin loading system for testing this approach is nearly full scale with respect to a comercial recycle plant. 
Continuous ion exchange contactors have been developed and might be used whih the continuous nitrate extraction to give continuous resin loading. Two principal advantages could be realized from this combination. One is that the resin loading could be operated at steady state throughout without the fluctuats $\mathrm{ns}$ inherent in batch operation. In practice, hovever, this is not necessarily a simplification or improvement since the cortrol of rates to give steady-state operation is more complicated than operating at a fixed rate to a selected end point. The second advantage is easier control of nuclear criticality for larger capacities. One cortinuous loading system of critically safe dimensions could give capacities triat would be equivalent to 20 to 50 batches per day for batch loadiäg contactors. However, a commercial ${ }^{233} \mathrm{U}$ recycle plant would only require siz to eight batches per day.

It appears that efther continuous or batch loading contactors could be efficiently used for $25 \mathrm{~kg}$ of uranium per day. Batch loading would probably be more efficient for capacities less than $25 \mathrm{~kg} / \mathrm{day}$, whtle cortinuous loadiag would be more efficlent for capacities greater than $25 \mathrm{~kg} / \mathrm{day}$.

\subsection{Basch Resin Loading Contactor}

Descriptions of the design and the fluidization behavior of the batch loading contactor are given here. The overall process behavior and control of the compiete system are described in Sect. 7 .

The batch resin loading cuntactor was a 5-in.-ID, 60-in.-1ong cylinder with a cone bottom and a 120-mesh stainless steel screen top (F1E. 7). The 5-in.-ID dimension was the maximum allowable for control 
ORNL DWE 77-397 RI

FEED RESIN IN

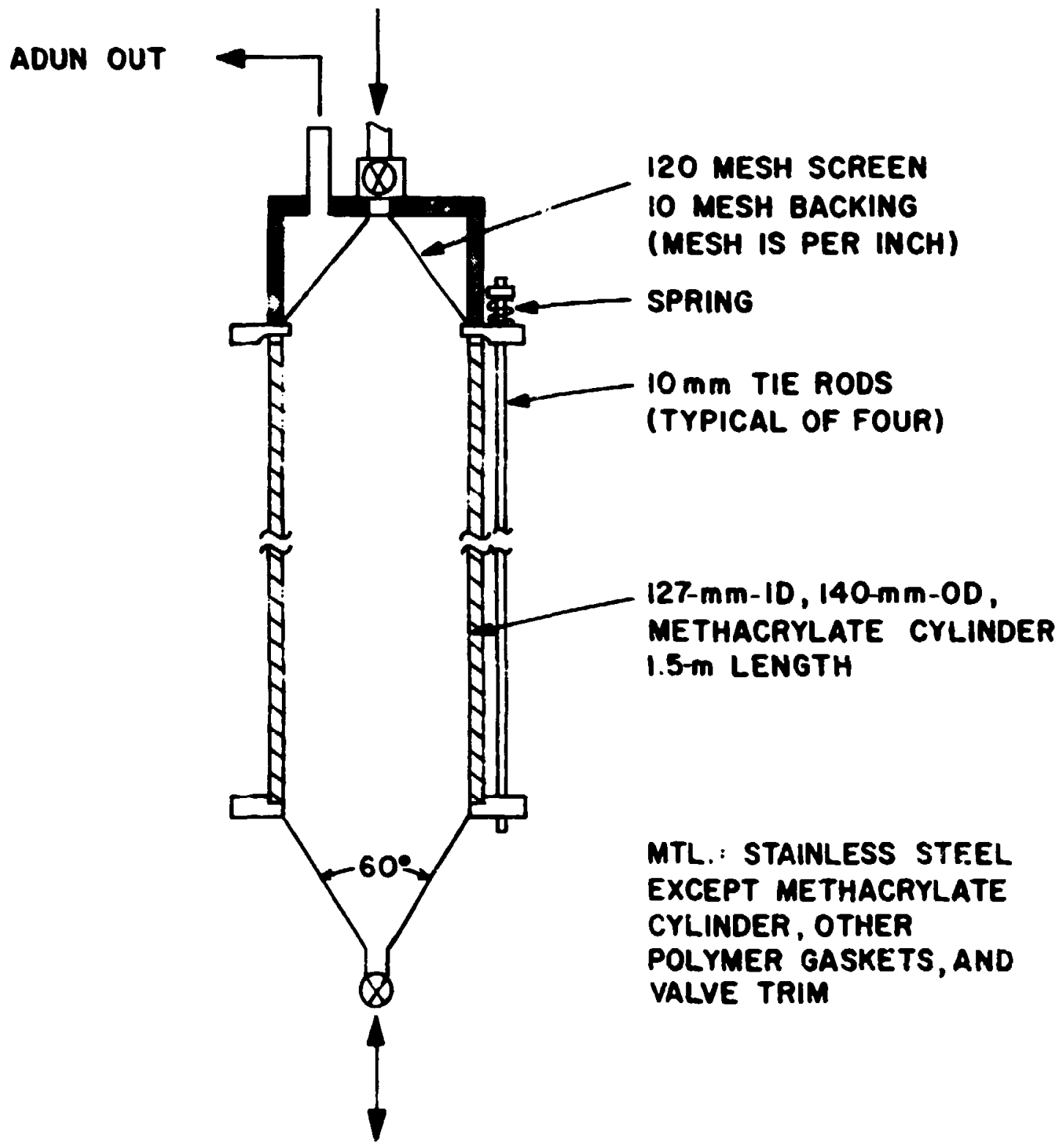

ADUN IN OR LOADED RESIN OUT

Fig. 7. Cross-sectional view of batch loa ling contactor. 
of nuclear criticality. The 60-in. cylinder length gives a total volume of 20 liters, while the setcled volume of one batch of resin is 11 to 13 liters. The extra volume is necessary to allow reasonable inftial ADUN flars without packing the resin against the exit screen.

Some design detalis of the test unit are shown in Fig. 7; however, the pilot plant would use different naterials and assembly detalls. The top flange and screen assenbly was essentially Identical to that designed and described for the resin dryer (see Sect. 4.3). The transparent walls allored observation of the hydraulic and nixing behavior, but this is not necissary since a schedule of flow rates can be specifled without observation of the resin.

The batch loading contactor generally shows several mixing cells Instead of one uniformly mixed bed. The center encry and the cone bottom result in a spouting bed type of operation in the bottom one-fifth of the contactor. Above this, there are two or war? cells with upflow at the center, downflow at the walls, and center-to-wall or wall-tocenter flows at the top and bottom of each wixing cell. The poorest mixing occurs at the bottco corner between the cylinder and the bottom cone. While mixing in this region is incomplete during the Initial period of low ADUN flow, satiofactory results are obtained after the ADUN flow 1. Increased.

Plugging of the 120-mesh top screen by resin fines was detectable but did not cause operating problems. In pllot-plant operation, the feed resin would be more carefully screened and would therefore contain a much smaller frection of fines. The screen mesh could be changed to a larger opening size to eliminate accumulation of fines on the screen. 


\subsection{Continuous (Higgins) Resia Loading}

A continuous, 2-in.-ID resin loading contactor of the Higgins type was tested as a replacenent for the batch laading contactor in the engineering-scale resin loadiuy sysičñ. The results have been reported elsewhere ${ }^{7}$ and thus will only be sumarized here. The results indicate that the 2-in.-ID Higgins contactor can eastly load $25 \mathrm{~kg}$ of uranium per day, implying that a 4-in.-ID Higgins ccntactor can $10 a d 100 \mathrm{~kg} / \mathrm{day}$. The process control requirements were investigated with particular emphasis on remote operation. In addition, the 2-in.-ID Higgins contactor was successfully used to convert sodium-form resin to the acid form. The conclusions as reported ${ }^{7}$ include the following:

1. Adequate process control has been demonstrated for the continuous loading of cation exchange resin with uranium.

2. Remote operation appears to be feastble with existing instrumentation.

3. The existing equipment can supply an acceptable resin product at the rate of $1.4 \mathrm{~kg}$ of uranium per hour.

4. Scaling up to $1.00 \mathrm{~kg}$ of uranium per day can be achieved by using a 4-in.-ID Hizsins contactor of critically safe dimensions.

\section{DRYING OF URANIUM-LOADED RESIN}

The selection, design, and testing of a microwave-heated dryer as part of the engineering-scale resin loading system have been reported. 8 Microwaves are electromagnetic waves in the frequency range of $300 \mathrm{MHz}$ to $300 \mathrm{GHz}$, with corresponding wavelengths of $1 \mathrm{~m} \mathrm{to} 1 \mathrm{~mm}$. Microwaves have many of the same characteristics as light waves; that is, they 
can be generated, reflected, transitted, and absorbed. Of course, there are basic differences in the naterials that transint and absorb then, as we 11 as in the anner in which each is generated. When an electromagnetic wave is propagated in a fielectric naterial, the wave is attenuated and power is thereby dissipated in the waterial in the form of heat. Water has certain nolecular properties that enable it to absorb nicrowave energy.

Mcrowave drying has several advantages over conventional heating, which relies primarily on conduction-convection. These include instant "on-off" capability, molsture leveling (1.e., preferential heating of the wettest materfal), and a shorter drying cycle without high cemperatures. Microwave heating has satisfied our needs better than any other methods considered for this application with geometry restrictions, poor thermal conductivity of the resin, and uniformity requirement.

\subsection{Capacity}

The engineering-scale resin loading system is designed for batch loading of resin at $4 \mathrm{~kg}$ of uranium per batch. While the pilot-plant capacity is based on one bacch per day, the resin loading operations require $4 \mathrm{hr}$ per bacch or less. The nitrate extraction system is continuous with a uranium capacity equivalent to at least $1 \mathrm{~kg} / \mathrm{hr}$. If the complete cycle for the resin dryer (including loading, washing, drying, and unloading) does not exceed $4 \mathrm{hr}$, a single dryer could serve a continuous nitrate extraction system with either multiple bacch contactors or a continuous resin loading contactor. About $2 \mathrm{~kg}$ of water should be evaporated to dry one batch of rissin to a preferred water content (discussed in Sect. 4.2). 


\subsection{Specifications for Dried Product}

These specifications remain to be determined or to be verified. In general, the primary specifications are those for the carbonized and/or coated kernels; in addition, the dried, uranium-loaded resin must be sultable for carbonization, conversion, and coating to meet those primary specifications. The size, shape, sphericity, uranium content, and impurity content of the kernels are determined and controlled by resin feed preparation and resin loading operations. The specifications of greatest Importance to the drying of the resin are as follows:

1. The shape of the kernels must not be degraded by cracking, clustering, or other changes during drying.

2. Any material added should be free of impurities that would change the composition of the carbonized kernels or that would result in uncontrolled variations in the carbon and oxygen contents after carbonization.

3. The water content of the dried resin should be within an optimum range for the requirements for accountability, handling, and carbonization.

Specification of the water content for the dried, uranium-loaded resin is now 10 to 202 LOD fran a compromise of conflicting requirements. The water content is generally determined as a percentage LOD for overnight exposure to ambient afr ai $110^{\circ} \mathrm{C}$. The primary requirement fur accountability is that the $L O D$ be reproducible and uniform. Treatment of the carbonization off-gases, including control of criticality, is simplified by minimizing tive amount of water charged to the carbonization furnace. 
These two requirements resulted in an initial selection of less than 0.1 wt $Z$ LOD as a specification for dried resin. For less than 0.1 wt $Z$ LOD, the dried resin shous static charge effects which make handing and transfer very troublesone. The resin 11terally cliabs the valls of all surfaces exposed to it and cannot be poured or transferred pneunatically without leaving sowe of the particles behind on surfaces. Addition of graphite poicers vas tested, but this only alleriates the problea without elfininating it and is an undesirable process complication. Empirical tests showed that 10 to 20 LOD for uranfum-loaded Amberlite IRC-72 results in acceptable handling properties. Static charge problems become increasingly noticeable as the LOD decreases below 10 wt $\%$. The resin appears to become increasingly sticky from dampness as the LOD increases above 20 wt $\pi$. The alternate resin, Duolite $\mathrm{i}-464$, is slightly more forous and shows the same behavior at a slightly higher LOD; 12 to 24 wt 7 gives optimum handing behavior.

\subsection{Description of the Microwave Dryer}

A microwave energy system for drying uranium-loaded ion exchange resin was purchased from a comercial manufacturer ${ }^{\star}$ and tested. A schematic diagram 1llustrating the components of the microwave dryer system is stown In Fig. 8. The microwave cavity (applicator) is constructed of $0.16-c m-$ thick type 304 stainless steel and has dimenstons of $1.2 \mathrm{~m} \mathrm{high} \times 1.2 \mathrm{~m}$ wide $\times 0.9 \mathrm{~m}$ deep. The resin container is a $13.0-\mathrm{cm}-00 \times 0.3-\mathrm{cm}-w a 11 \times$ 1.2-m-1ong Pyrex tube. The colum is a vessel of safe geometry with respect to nuclear criticality and provides ample freeboard to allow fluidization and mixing of the resin. At atatic conditions, the reference

\footnotetext{
*Gerling Moore, Inc., Palo Alto, Calff.
} 


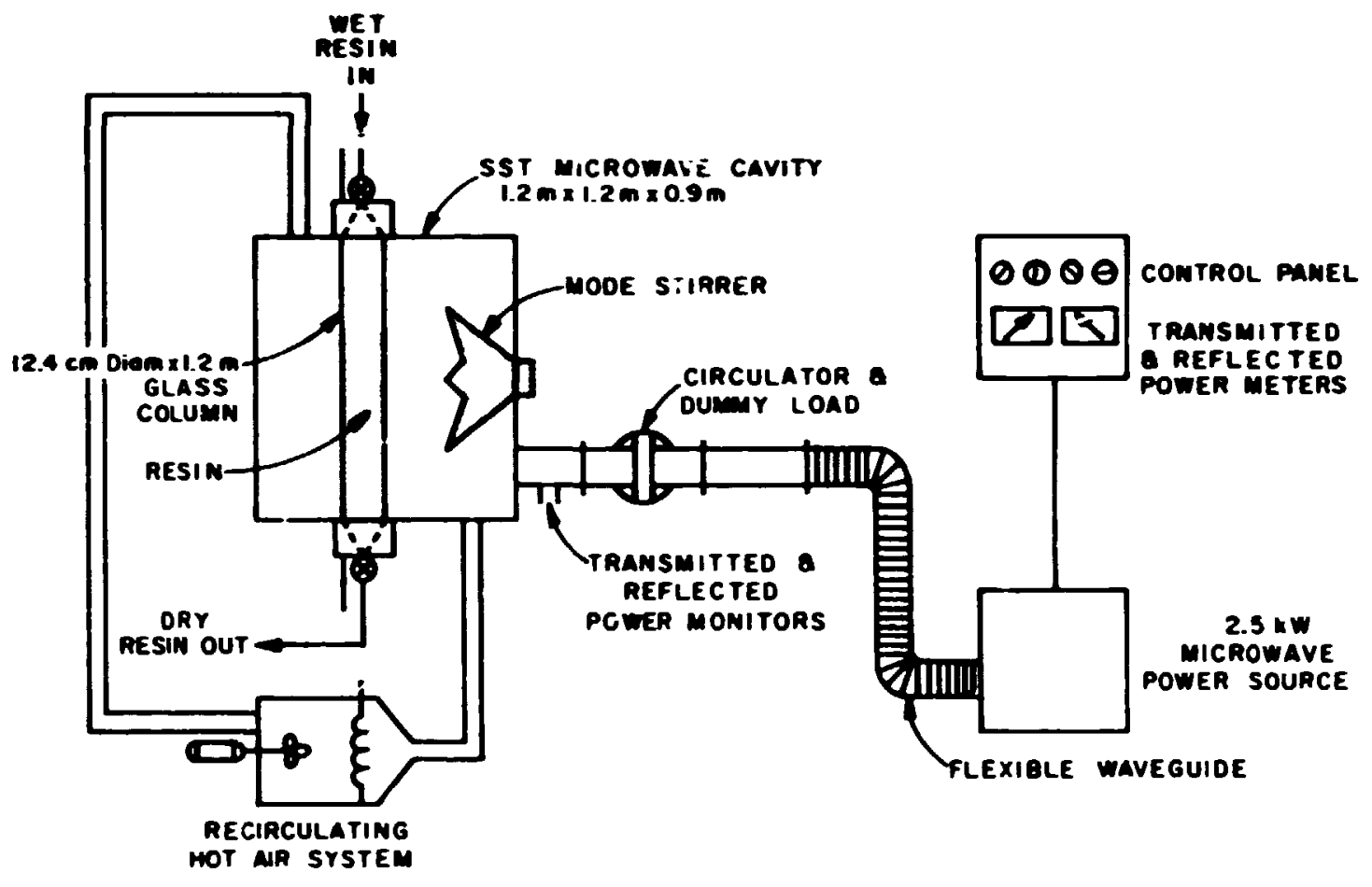

Fig. 8. Mcrowave-heated dryer used in the preparation of uraniumloaded ion exchange resin. 
11-11ter resin batch occupies approximately $75 z$ of the colum. The width and depth of the cavity, as well as the location of the column, were selected by the aicrowave system manufacturer. Provisions for solids addicion and withdrawal (as well as liquid or vapor only, through screens) are incorporated in a spectal flange assembly (Fig. 9). This flange has a confical $\left(245^{\circ}\right.$ slope), 120-mesh sareen with a hole at the apex. A 1.9-cm ball valve is secured to the plate to allow retention and transfer of solids. The flange and screen are fabricated from type 304 stainless steel. During the drying cycle, alr is passed through the resin bed to aid ir. water vapor removal and to promote mixing of the material. The saturated afr leaving the column is passed through a condenser, and the condensate is collected.

A recirculating hot air system reduces heat transfer from the resin colum to the surroundings during the drying cycle. A 2-kW space heater and blower directs heated air into the cavity. The temperature inside the cavity is maintained at approximacely the steady-state temperature of the column exit gas strean (typically, 70 to $80^{\circ} \mathrm{C}$ ) during the microwave heating period. (The outglde top and side walls of the cavity were Insulated.) When this heater is not operated, water condenses on the glass coiumn.

The microwave power source (magnetron) is a varlable-power generator wth an operating range of 0 to $2.5 \mathrm{~kW}$ at $2.45 \mathrm{GHz}$. The $2,45-\mathrm{CHz}$ band was selected over the $915-\mathrm{MHz}$ band because the highe: frequency produces a shorter wavelength (and therefore more modes in a given cavity size) and consequently a; is more uniform heating. A standard rectangular rigld 


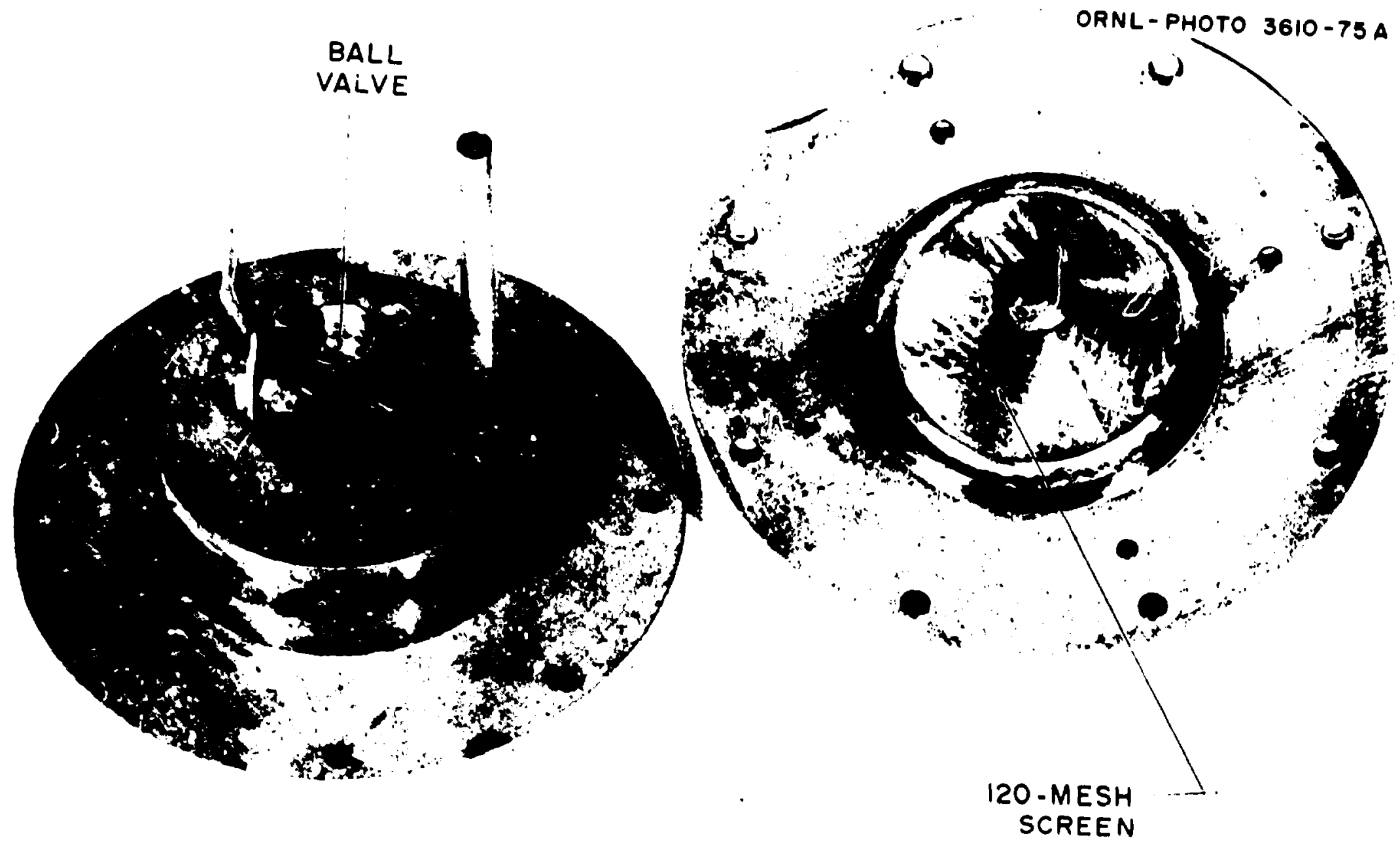

Fig. 9. End sections of resin dryer in microwave cavity. 
waveguide, bends (elbors), and a $1-m$ length of $f$ lexible waveguides were used to couple the power supply to the cavity. A quartz vindow diaphragm is located between the vaveguide $f$ lange and the cavity wall to prevent material from entering the vaveguide. Flexible waveguide is manufactured frow silver-plated interleaved brass and can be fabricated in any length up to $1.5 \mathrm{~m}$. This flexible waveguide can nake a $90^{\circ}$ twist or bend in 31-ce lengths. Standard rectangular waveguide is camonly fabricated from aluminum. The straight wavegulde is avallable in stainless steel; however, the flexible wavegulde cannot be purcinased in thls form.

\subsection{Results Obtalned by Mcrowave Drying}

Microwave heating was successfully demonstrated to give concrolled and reproducible drying of 11-11ter batches of uranfum-loaded ( $4 \mathrm{~kg}$ of uranium) resin in a vessel of safe dimensions for nuclear criticality (12.4 $\mathrm{cm}$ ID). The dried resin should have a water content of 10 to 20 wt $Z$ to minimize handling problemg. The microwave heating evaporates water throughout the resin bed, with preferential heating of the wettest resin, and allows short drying cycles.

A standard drying procedure and methods for determining the duration of microwave heating, In order to obtain the desired water content, were developed. Use of an experimentally derived drying factor or monitoring the amount of water removed from the wet resin has been found to provide reproductbly acceptable dried product. Temperature or reflected power was not reliable in obtaining resin of the preferred molsture content.

A heat balance on the resin dryer system and the coupling effictenciev of the microwave energy with the wet resin were calculated and found to be 
in good agreement with experimental results and the manufacturer's literature respectively. The minimum fluidization velocity was also calculated anci found to compare favorably with experimental observations. Mixing of the naterial was found to be required in order to ensure a unf orm moisture content. No significant operatir.g difficulties were encountered. Detailed results and procedures have been reported elsewhere. 8

\section{EVAPORATOR}

Design, fabrication, and testing of a thermosiphon evaporator as f: rt of the engineering-scale resin loading system have teen reported. 9 Figure 10 is a schematic flowsheet of the vertical thermosiphon evaporator. Uranyl nitrate is supplied by a centrifugal pump to the evaporator feed nozzle located near the liquid inlet of the reboller. The feed rate is usually two to three times the condensate rate. Concentrated uranyl nitrate is cooled to the resin system process temperature before returning to the UNH surge tank via a fixed jackleg (overflow weir). Vapor passes through the disengaging section and a wire-mesh mist eliminator. The entrainment-free vapor is condensed and the condensate collected. The overflow weir and condensate tank are on a corrnon vent line. The type $304 \mathrm{~L}$ stainless steel evaporator is of all-welded construction.

The thermosiphon evaporator was simple and easy to control. The fixed jackleg maintains a constant liquid level in the evaporator and permits continuous circulation through it. The evaporation rate (and hence the uranium concentration in the resin loading system) was controlled by regulating the steam pressure while maintaining a constant rate 
ORNL-DWG 75-17868R2

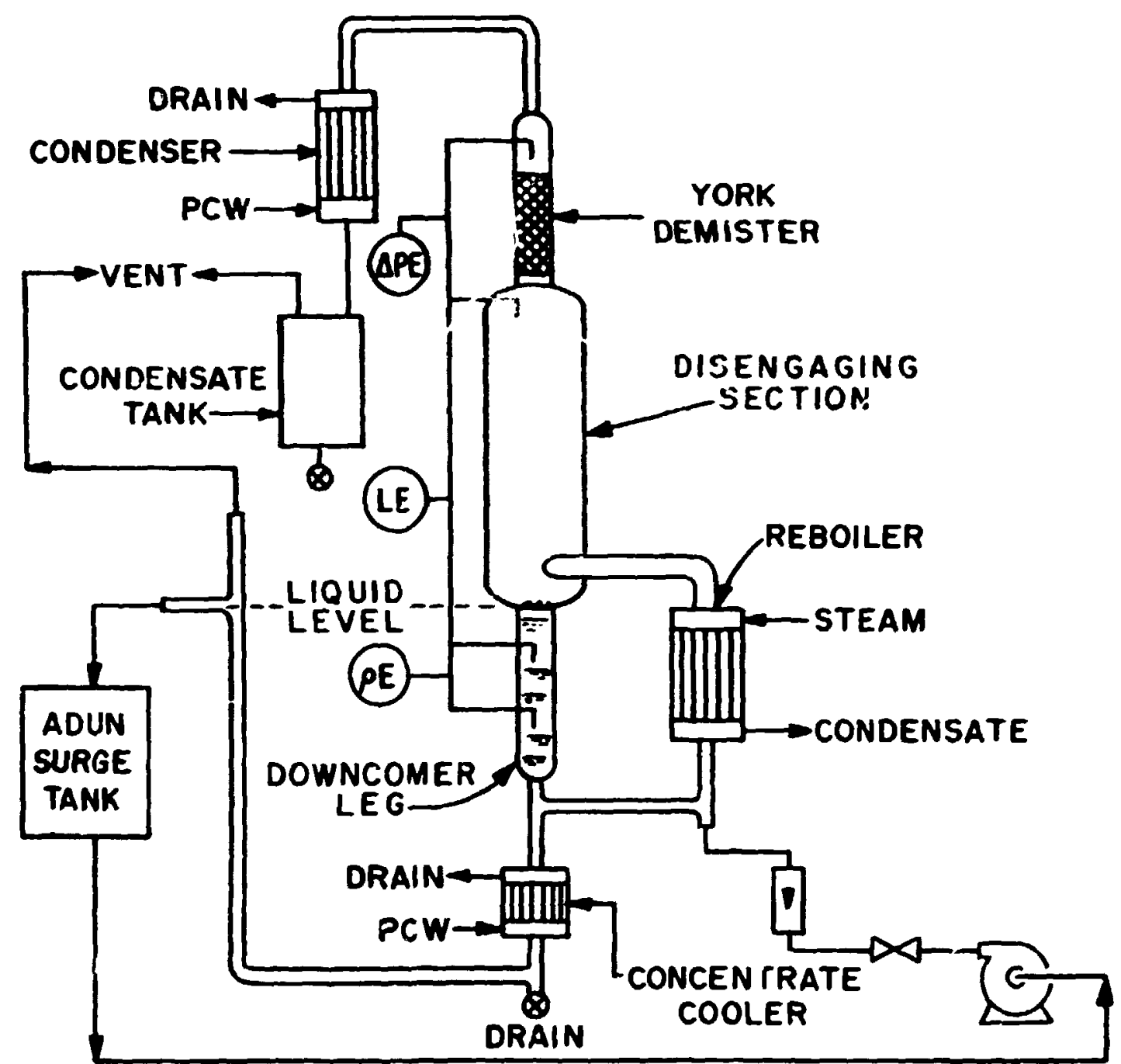

Fig. 10. Vertical thermosiphon evaporator. 
of feed flow to the evaporator. A high-quality condensate containing less than $0.5 \mathrm{ppm}$ of uranfum, for an overall decontanination factor of greater than $5 \times 10^{5}$, is obtained by utilizing a tangential yapor entry to the large vapor disengaging section and a wire-mesh mist separator. The decontanination factor was not a consistent function of the condensate rate for rates of 17 to 79 liters/hr. This evaporator design is acceptable for weeting the HTGR fuel recycle pilot plant requirements. Detafls of the design and results have been reported.

When highly acld-deficient uranyl nitrate is heated to temperatures above $100^{\circ} \mathrm{C}$, precipitation of uranium occurs. This precipitate is easily dissolved at lower temperatures or higher $\mathrm{NO}_{3}{ }^{-} / \mathrm{U}$ ratios. The nomal operating procedure for the engineering-scale resin loading system limited evaporator operation to periods of higher $\mathrm{NO}_{3}^{-} / \mathrm{U}$ ratios and used continued flow through the evaporator at lower temperatures to dissolve any fiecipitated uranium. In future systems, the evaporator should probably be fed with the more acicic uranyl nitrate from the resin loading contactor in order to further minimize prectpitation of uranium.

\section{NITRATE EXTRACTIOA}

The nitrate extraction system consists of a series of five cocurrant (one theoretical stage of contact each) contactors (Fig. 11). A single solvent stream ( $0.4 \mathrm{M}$ Amberlite LA-2 secondary amine) is pumped once and flows, via gravity, through all five contactors back to the solvent surge tank. An aqueous stream is metered to each contactor and exts through a jackleg and weir to control the aqueous-organic interface level. The mixing sectlons are organic continuous to improve the phase separation, 


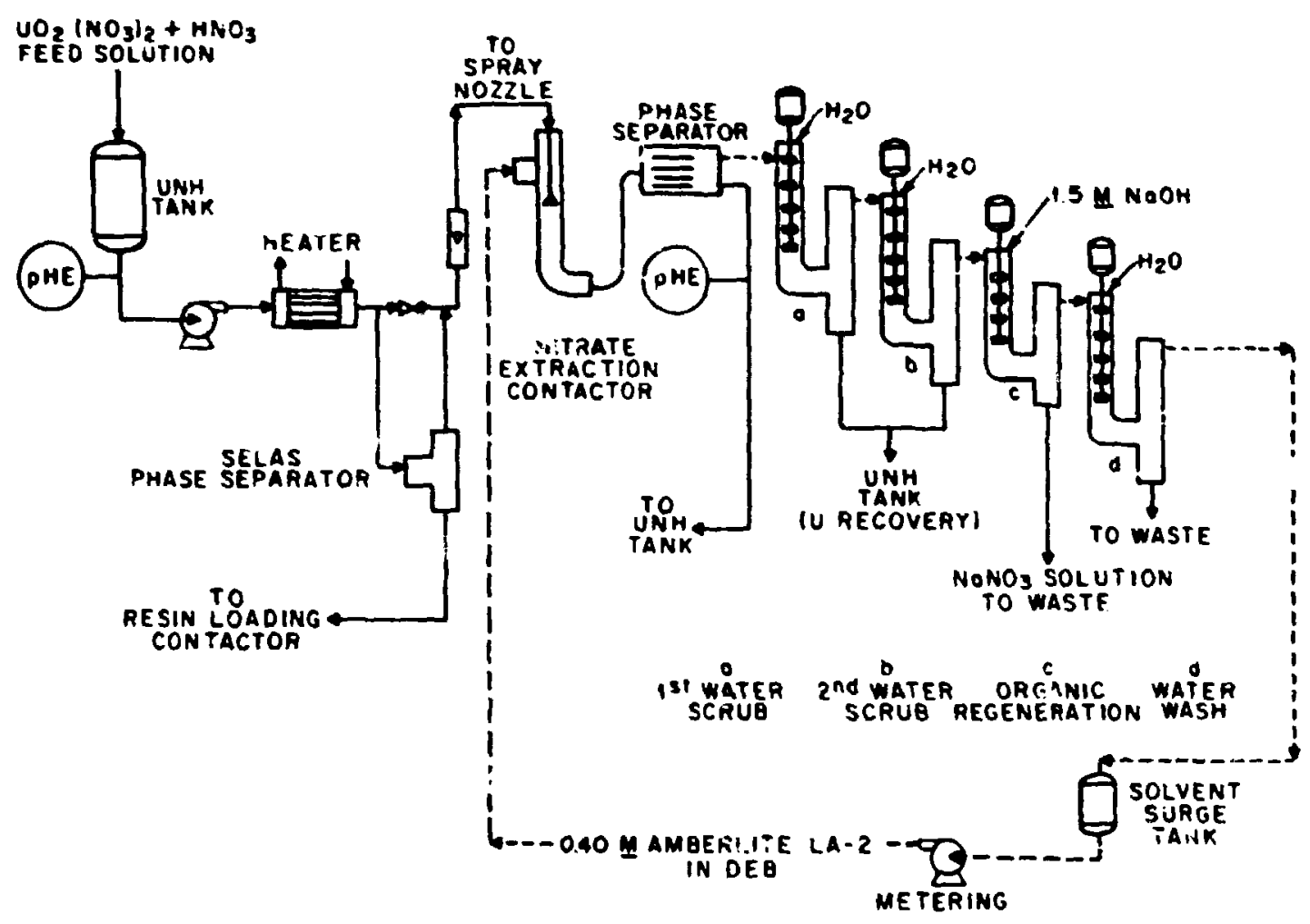

Fig. 11. Process flows of nitrate ion for resin loading. 
and the organic-air Interface level is controlled by a weit for the exit organic. In the engineering-scale resin loading system, the highest contactor to which the organic is pumped is a spray colum for extraction of nitric acid from the ADUR:. The other four contactors have high organic/ aqueous flow ratios and require mechanical agitation to imf mus their efficiencies. The first two are water scrubs to recover urantum for retura to the ADUN tank. The third is the regeneration contactor with NaOH (or other base) solution feed. The final contactor has a water feed to scrub entrained aqueous waste from the solvent. The aqueous effluents from the third and fourth contactors are waste solutions with approximetely neutral pH values.

The nitrate extraction system components had been designed, fabricated, and operated earlier for sol-gel processes. The spray contactor was a modification of that used for preparing urania sols. 10 The mixer-settler contactors and solvent system were designed as prototypes for the preparation of $\mathrm{ThO}_{2}{ }^{-233} \mathrm{UO}_{3} \mathrm{sols}^{11}$ and had been operated for demonstration runs. 12

\subsection{Nitrate Extraction Equipment}

Uranyl nitrate solution from the ADUN tank was pumped through a filter, a Kates flow contzcller, a conductivity cell. with temperature element (thermocouple), a heater, a flow element (orifice and differential-pressure cel1), and a nozzle with 1/8-in.-diam holes below the solvent-air interface in the extraction column (F1g. 11). The aqueous drops flow cocurrently with the continuous organic phase down a 2-1n.-ID, 36-1n.-10ag contactor. Phase separation with interface control was achieved with several varlarions 
of new components and is described separately, along with the results obrained, in Sect. 6.2.

The solveat regeneration contactors may be overdesigned with respect to meeting the florsheet requirements. Each mixer-settler (Fig. 12) is made of 3-In.-diam glass pipe to permit observation of the process streams and operating characteristics. It is divided into six compartments, each of which has a mixing impeller; these impellers are mounted on a cownon shaft with a vartable-speed drive. The aqueous and organic phases enter at the top and flow cocurrently down through the six compartments to give the effect of mixing vessels in series. This arrangement ensures good stage efficiency. Since the mixer is designed to rematn filled with organic, the aqueous phase is dispersed into the organic phase (organic continuous) to minimize emulsification. At shutdown, the aqueous phase drains to the bottom; consequently, only the organic phase is present in the mixer at startup, ind the aqueous stream is eas $11 y$ dispersed as it enters. Each $m^{i}$ xer is equipped with wo U-shaped sections of stainless steel tubing through which hot water is circulated to maintain the organic and aqueous phases at about $50^{\circ} \mathrm{C}$. As initially installed, phase separation occurs in the section located below the mixer. The position of the interface is controlled by adjustable weirs on both the aqueous and the organic overflow lines. The nominal volumetric holdup of the mixing section is 2.0 11ters, while that of the settler 182.8 11ters of organic phase and 1.511 ters of aqueous phase. An Improved arrangement, which was installed and rested, is recommended for in-cell use. This is described separately in the following section. 


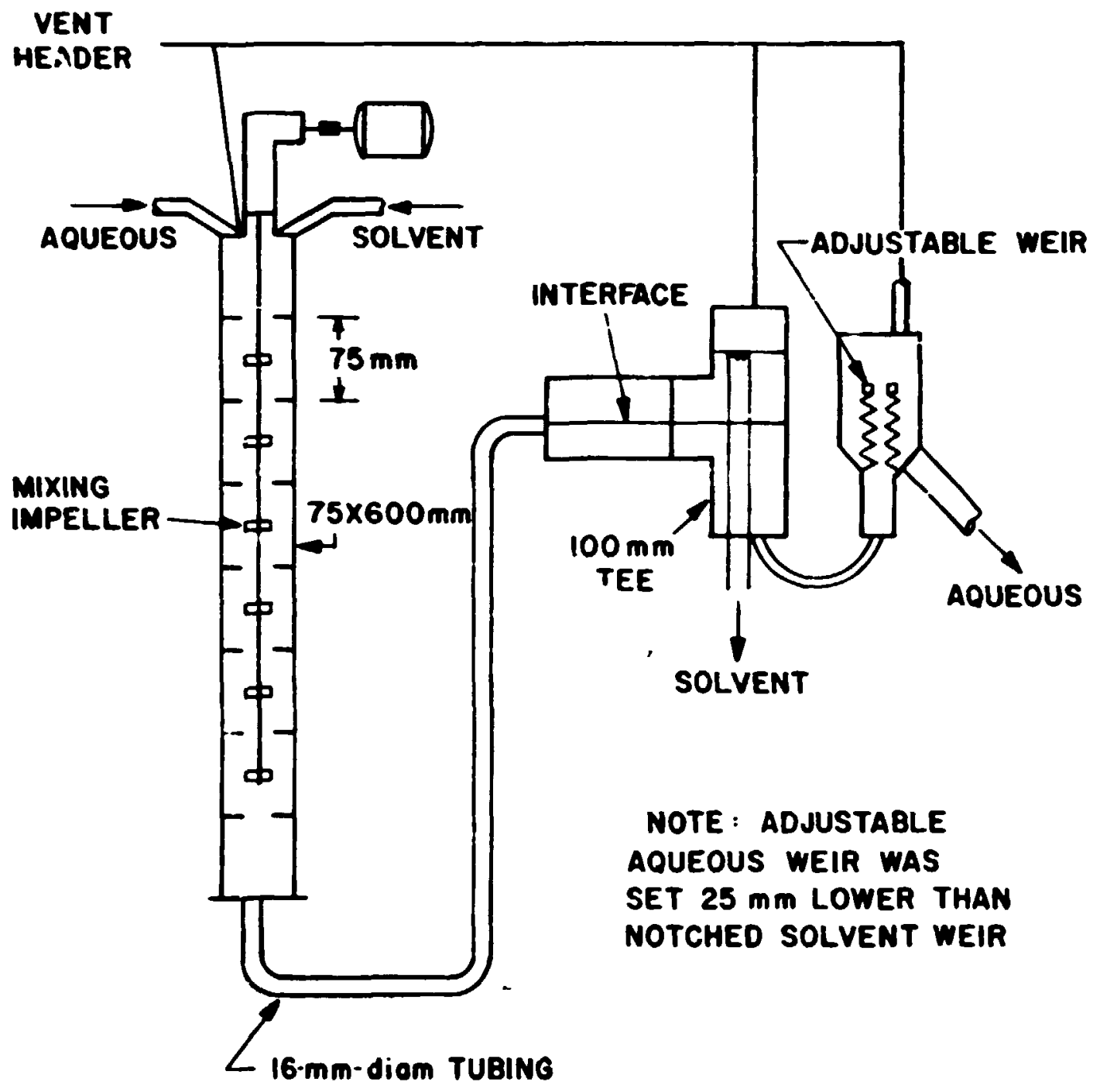

F18. 12. Mixer-settler for solvent scrib and regeneration stage:; 


\subsection{Phase Separation and Interface Control}

Separation and control of the two phases after leaving the mixers are necessary in order to achieve satisfactory operation. Carry-over of organic into aqueous wastes would aake waste handling wre troublesoce and would require replacerent of the lost solvent. Organic in the ADWN to the resin loading would accumulate ca the resin and, when present in large amounts, would Interfere with the loading of iranium. Snall carryovers of aqueous streams in the organic only result in small losses of efficiency since the primary nitrate extraction and ane regeneration are each followed by water scrubs which would return aqueous to the same ADUN or waste tanks. These results of poor phase separation are listed as Table 1.

Detection and feedback control of the regeneration system interfaces would be troublesome and undesirable for an In-cell system. Overflow weirs are simple, Inexpensive, and less likely to malfunction than - control valve system. The solvent extraction system, as initially adapted, 3 required large changes in weir helghts to compensate for variations in liquid density. The largest varlations were from uranium concentration changes In the ADUN and frum temperature changes for the organic solvent. The liquid-11quid interface position results from a pressure balance, as follows:

$$
H_{O} \rho_{0}=H_{A} \rho_{A}
$$

where

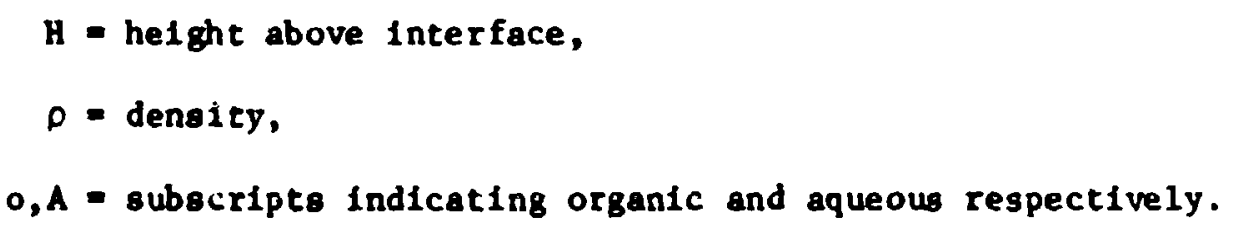


Table 1. Effects of poor phase separation

\begin{tabular}{|c|c|c|}
\hline $\begin{array}{l}\text { Contactor and } \\
\text { exit streams }\end{array}$ & $\begin{array}{c}\text { Effect of aqueoug carry-ovar } \\
\text { with organic }\end{array}$ & $\begin{array}{l}\text { Effects of organic } \\
\text { carry-over with aqueous }\end{array}$ \\
\hline $\begin{array}{l}\text { Nitrate extraction } \\
\text { (ADUN and amine nitrate } \\
\text { in DEB) }\end{array}$ & $\begin{array}{l}\text { More uranium to be recovered in } \\
\text { scrub contactors, and a minor } \\
\text { increase in uranium losses to } \\
\text { nitrate waste }\end{array}$ & $\begin{array}{l}\text { Organic in ADUN tank } \\
\text { (and to ADUN pump) }\end{array}$ \\
\hline $\begin{array}{l}\text { First } \mathrm{H}_{2} \mathrm{O} \text { scrub } \\
\text { (dilute ADUN and amine } \\
\text { nitrate in DEB) }\end{array}$ & $\begin{array}{l}\text { More uranium to second scrub, and } \\
\text { minor increase in urantum losses } \\
\text { to nitrate waste }\end{array}$ & $\begin{array}{l}\text { Organic in ADUN tank } \\
\text { (and to ADUN pump) }\end{array}$ \\
\hline $\begin{array}{l}\text { Second } \mathrm{H}_{2} \mathrm{C} \text { scrub } \\
\text { (very dilute ADUN and } \\
\text { amine nitrate in DEB) }\end{array}$ & $\begin{array}{l}\text { Minor Increase in urantum losses } \\
\text { to at trate waste }\end{array}$ & $\begin{array}{l}\text { Organic In ADUN tank } \\
\text { (and to ADUN pump) }\end{array}$ \\
\hline $\begin{array}{l}\text { Amine regeneration } \\
\text { ( } \text { NaNO }_{3} \text { solution and } 75 \% \\
\text { amine--25\% amine nitrate } \\
\text { in DEB) }\end{array}$ & $\begin{array}{l}\mathrm{NaNO}_{3} \text { to final } \mathrm{H}_{2} \mathrm{O} \text { scrub, and } \\
\text { minor Increase in sodium carry- } \\
\text { over to ADUN }\end{array}$ & $\begin{array}{l}\text { Loss of solvent to } \mathrm{NaNO}_{3} \\
\text { waste }\end{array}$ \\
\hline $\begin{array}{l}\text { Final } \mathrm{H}_{2} \mathrm{O} \text { scrub } \\
\text { (very dilute } \mathrm{NaNO}_{3} \text { and } \\
75 \% \text { amine-- } 25 \% \text { amine } \\
\text { nitrate in DEB) }\end{array}$ & $\begin{array}{l}\text { MAnor Increase in sodium carry- } \\
\text { over to ADUN }\end{array}$ & $\begin{array}{l}\text { Loss of solvent to aqueous } \\
\text { waste }\end{array}$ \\
\hline
\end{tabular}

$a_{D E B}=$ diethylbenzene. 
Equation (10a) can be rearranged to give:

$$
\begin{aligned}
& H_{A}=\left(H_{0}-H_{A}\right) \frac{\rho_{O}}{\rho_{A}-\rho_{0}}, \\
& H_{0}=\left(H_{0}-H_{A}\right) \frac{\rho_{A}}{\rho_{A}-\rho_{0}} .
\end{aligned}
$$

The usual densities $\left(\right.$ In $\left.8 / \mathrm{cm}^{3}\right)$ are: amine solvent $\left(\rho_{0}\right), 0.82 ; 1.5 \mathrm{M}$ $\mathrm{NaNO}_{3}, 1.075$; scrub water, 0.99; and ADUN [see Eq. (4a)], 1.09 for $0.3 \mathrm{M}$ uranium. For fixed interface positions, $\mathrm{H}_{\mathrm{O}}-\mathrm{H}_{A}$ is fixed. For the original arrangement shown by Fig. 13(a), the $H_{A}$ were about $70 \mathrm{~cm}$ and Interface variztions would be as large as $15 \mathrm{~cm}$ for fixed welrs. Such large variations would not be tolerable. For the arrangement shown in F1g. 13(b), the $\mathrm{H}_{A}$ are about $10 \mathrm{~cm}$ and the resulting interface variations (up to $2 \mathrm{~cm}$ ) are acceptable. This modification was demonstrated for both the nitrate extraction and the caustic regeneration contactors. Results were as expected; no difficulties were encountered.

The mixing requirements and the effects of temperature initially reported $^{3}$ were confirmed. The phase separation, although ${ }^{-}$adequate at $25^{\circ} \mathrm{C}$, is vistbly faster at $40^{\circ} \mathrm{C}$. Since radiochemical cells are usually warmer than $25^{\circ} \mathrm{C}$, the high, emperature is easier to maintain chan $25^{\circ} \mathrm{C}$. The effects of temperature in the 40 to $60^{\circ} \mathrm{C}$ range as: not important. Details of the contactor designs have been reported previously. 11 The contactors have six stages with cocurrent flow using i common agitator with a 1-3/4-in.-diam by 1/2-in.-high impeller in each stage. For the resin loading flowgheet, these agitators must be operated at 350 to 500 rpm to achieve optimum results. 
OANL Dewg 76-209s2ai

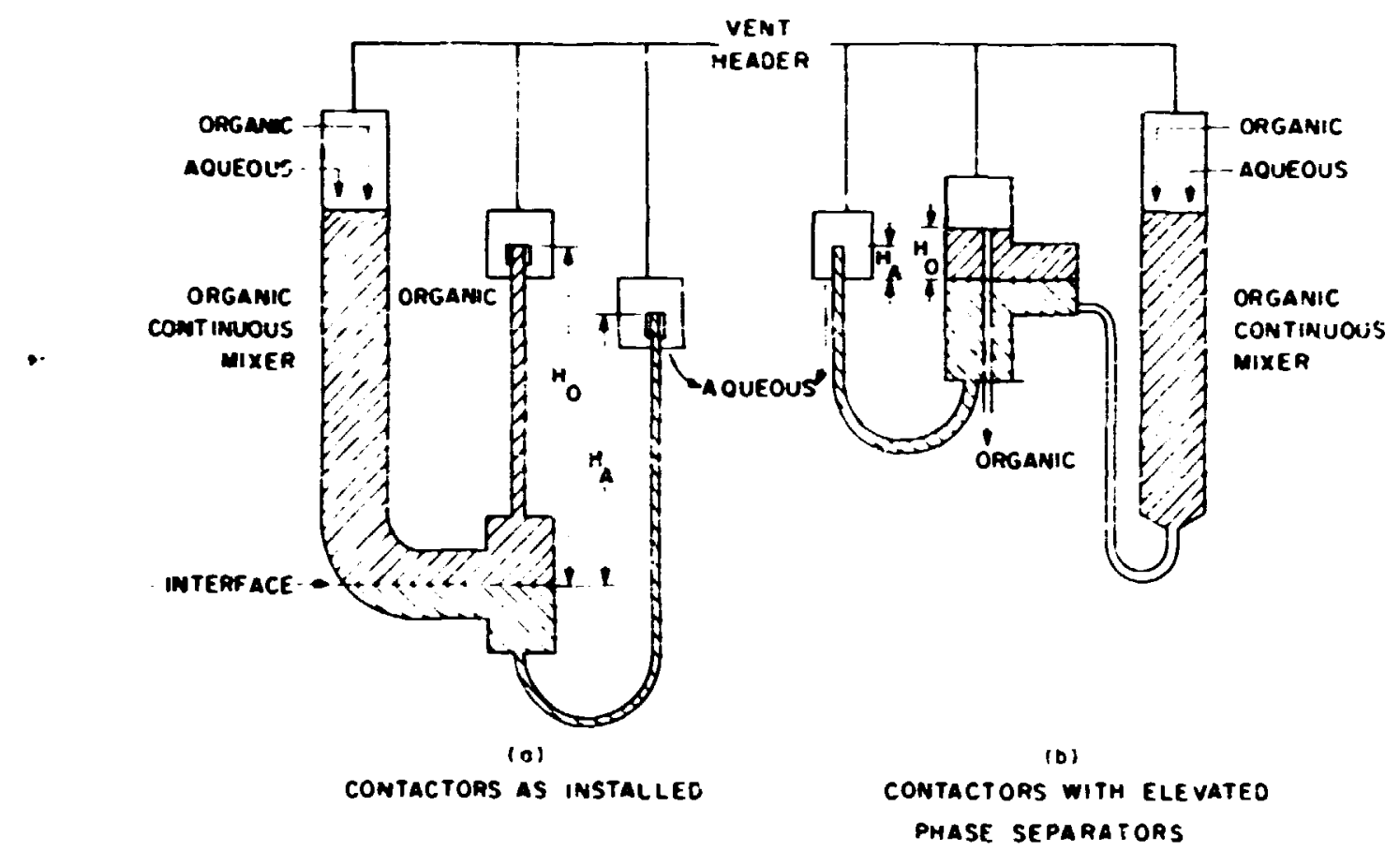

Fig. 13. Interfaces in nitrate extraction and amine regeneration contactors for resin loading. 
A standard centrifugal pump rotating seal (John Crane type 9) made of alumine and graphite was used for the contactors. This seal is capable of operating when the interior of the contactor is evacuated. Support for the impeller shaft is located above the rotating seal in a $2: 1$ right-angle speed reducer (Crown Gear Hodel ij4). The Impellers are attached to the extended low-speed shaft. A vartable-speed wotor and the 2:1 speed reducer 11mit the speed of the impellers to $875 \mathrm{rpm}$.

A membrane type of separator was tested on the ADUN flowing to the resin loading contactor to prevent organic entrainment. The ADUN was passed through a membrane which rejects organic drops. The rejected organic and excess ADUN fliwed to the nitrate extractios contactor and phase separator. This unit was effective for preventing organic carry-over to the resin loading step. However, the meabranes also arted as filters and showed signs of plugging during long-term use. The membrane materials are of unknown composition and might be sensitive to radiation damage from 232 U. Simple gravity separation by an enlarged tee 18 recommended for in-cell use since the potential problems from the membranes are more important than a more efficlent phase separation.

The amounts of organic in ADUN samples were determined by analyses for total carbon content. The results ${ }^{i 3}$ show less than $100 \mathrm{ppm}$ of carbon with some removal of carbon by the Ion exchange resin during the first third of the loading. The tutal carbon accumulated on the resin would be less than $1 \mathrm{~g} / 11 \mathrm{ter}$, or $1000 \mathrm{ppm}$, for the drfed resin. This quantity is not expected to have any significant effect on the resin composition since most of it is probably volatilized by steam-stripping during the resin drying process.

*odel LS-60.-P, Selas Flotonics Corp., Springhouse, Pa. 


\subsection{Equipment Performance}

The nitrate extraction components, including the amine rogeneration system, have performed well. While the units designed for sol-gel processes were adequate for the development studies, several modif cations or changes seemed desirable to adapt them to remote operation. These included the following:

1. Elimination of visual observation and control of liquid-liquid Interfaces (see Sect. 6.2).

2. Changes or additions to facilitate phase separation (see Sect. 6.2).

3. Use of metal contactors instead of glass. Although glass equipment has been accepted for HETF use, demonstration of metal prototype contactors may be required as a test for future plants.

4. Use of multistage countercurient contactor in place of the four cocurrent contactors in the amine regeneration system. Unacceptable results for a packed colum will be described in this section. Pulsed columns could probably provide the wore effective mixing that is required, but the tendency for emulsifications to form at the NaOH solution inlet might be troublesome. Further tests of contactors are not scheduled.

5. The solvent was metered by Micro Bellows pumps (Research Appliance $\left.C_{0 .}\right)$. These pumps use cam-operated Teflon bellows with adjustable stroke lengths to vary the flow rates. Some other liquid flow control system might be preferred for remote operation. 
A 3-in.-ID by 6-ft-long packed column (3/8-1n. Raschig ring packing) was fabricated, Installed, and tested to replace the two cocurrent uixer-settler stages for recovering uranim from the nitrate extraction solvent. The packed column would be simpler me hanically, while a countercurrent contactor might provide more than two theoretical stages, thereby reducing the uranium content of the nitrate waste. During two test runs, the $6 \mathrm{ft}$ of packed colum gave only a fraction of a theoretical stage. The uranium losses were about $0.5 \%$ as compared with less than 0.057 for the two cocurrent mixer-settler stages. The aqueous scrub does not disperse into small drops in the packed column. A pulsed column contactor could probably be used as an efficient countercurrent scrubbing contactor.

\subsection{Partial Regeneration of Amine}

The third contactor in the regeneration system reacts the amine nitrate with aqueous solutions of bage to regenerate the free amine. Excess NaOH results in the formation of emulsions and is not allowable. The initial demonstration of amine extraction ${ }^{12}$ used equimolar mixtures of $\mathrm{NaOH}$ and $\mathrm{Na}_{2} \mathrm{CO}_{3}$. The solvent/aqueous ratio was selected to give complete regeneration of the amine with complete utilization of the $\mathrm{N} s \mathrm{OH}$, but only partial conversion of the $\mathrm{Na}_{2} \mathrm{CO}_{3}$ to $\mathrm{NaHCO}_{3}$ and $\mathrm{NaNO}_{3}$. The typlcal molar ratlo of $\mathrm{Na} / \mathrm{NO}_{3}{ }^{-}$in this waste was 1.7 . Partial regeneration of the amine using $\mathrm{NaOH}$ (or $\mathrm{NH}_{4} \mathrm{OH}$ ) only and a NaOH/amine ratio of about 0.7 is an important process improvement. The amount of waste salt is greatly reduced; the $\mathrm{Na} \mathrm{NO}_{3}{ }^{-}$ratio is $1.0 \mathrm{mcle} / \mathrm{mole}$. The waste is almost neutral (pH of 26 ), and phase separation is improved. The sclubility of uranium 
is minimized so that any large losses of uranium can be recovered by filtration. Tiese improvements for partial regeneration were demonstrated using both $\mathrm{NaOH}$ and $\mathrm{NH}_{4} \mathrm{OH}$ for regeneration. No difficulties were observed. One effect of partial regeneration is that the steacy-state rate of nitrate extraction is set by the caustic rate instead of the solvent rate. This is an advantage in that a fixed solvent rate can be used and the caustic rate is controlled by an easily maintained and checked metering system outside the cell. However, the ritrate extraction rate responds very slowly to changes in the caustic rate as a result of the solvent inventory of the system.

\subsection{Uraniun Losses}

The waste streams from the integrated resin loading flowsheet (Fig. 1) are the air and condensate from the resin dryer, a portion of the condensate from the ADUN evaporator, and the $\mathrm{NaNO}_{3}$ (or $\mathrm{NH}_{4} \mathrm{NO}_{3}$ ) solution waste from amine regeneration. The controlling amounts of uranium are present in the nitrate solution wastes from amine regeneration. The evaporator condensate contained less than $0.5 \mathrm{ppm}$ of uranium (see "ect. 5). The dryar condensate showed trace amounts of uranium ( $1 \mathrm{ppm}$ ) in a small volume of about 2 liters per batch. The amount of radioactivity in the form of particulates in the dryer off-gas would depend on the 1sotopic composition of the uranium, and on the type of resin feed used; only measurements of the condensate were made. An infrequent source of urantum losses would be replacement of the ADUN filter. Most of the uranium could be leached from this filter by acid and water washes, but measurements were not made. 
Table 2 tabulates the uranium concentrations in the aqueous streams of th: amine regeneration system for typical conditions. Since the vaste 1s $1.5 \mathrm{M} \mathrm{NaNO}_{3}$, the 50-ppa urantum content corresponds to 0.037 of the uranium loaded. The anounts of uranium in the uranium scrub flows are equivalent to about $0.5 \%$ of the original loading. Earlier tests with one uranium scrub contactor resulted in much higher vranium concentrations in the nitrate waste solutions. In the case of complete regeneration cf the amine with an excess of $\mathrm{NaOH}-\mathrm{Na}_{2} \mathrm{CO}_{3}$, the urantum was soluble at 300 and $600 \mathrm{ppm}$ (Table 3, runs S02, S03). For partial regeneration with NaOH or $\mathrm{NH}_{4} \mathrm{OH}$, the uranium precipitated and the samples for filtered waste showed uranium concentrations of 40 to $110 \mathrm{ppm}$ for $\mathrm{NaNO}_{3}$ solution and 6 to $21 \mathrm{ppm}$ for $\mathrm{NH}_{4} \mathrm{OH}$ solution. The decreased solubility of urantum for $\mathrm{NH}_{4} \mathrm{NO}_{3}$ as compared with $\mathrm{NaNO}_{3}$ at the same pH persisted after $24 \mathrm{hr}$ and has not been explai:ied.

The very high uranium losses for run sol (Table 3) result from the high uranium concentration of $0.7 \underline{M}$, which results in extraction of nitrate complexes as illustrated by Eq. (9). The uranfum Iosses were eastly controlled for urantum concentrations of 1 ess than $0.4 \underline{M}$ and $\mathrm{NO}_{3}{ }^{-} / \mathrm{U}$ ratios of 1.45 to 1.9 ; these 1 imits did no-present any drawbacks with regard to the resin loading.

\section{OVERALL PROCESS BEHAVIOR AND CONTROL}

The uranyl nitrate feed contains only $\mathrm{UO}_{2}{ }^{2+}, \mathrm{NO}_{3}{ }^{-}$, and water as major constituents. These are removed separately in the resin loading contactor, nitrate extraction contactor, and evaporator respectively. The uranyl 
Table 2. Uranium concentrations in aqueous streams from amine regeneration for typical flousheet conditions

Solvent flow: $0.6 \mathrm{liter} / \mathrm{min}$ of $0.4 \mathrm{M}$ Amberlite LA- 2 in diethylbenzene

Regeneration solution: $130 \mathrm{~cm}^{3} / \mathrm{min}$ of $1.5 \underline{\mathrm{M} \mathrm{NaOH}}$ Uraniun recovery scrubs: two contactors with $60 \mathrm{~cm}^{3} / \mathrm{min}$ of $\mathrm{H}_{2} \mathrm{O}$ to each

Final scrub: $30 \mathrm{~cm}^{3} /$ ain of $\mathrm{H}_{2} \mathrm{O}$

\begin{tabular}{|c|c|c|c|c|c|}
\hline \multirow[b]{2}{*}{$\begin{array}{c}\text { Run } \\
\text { number }\end{array}$} & \multirow[b]{2}{*}{$\begin{array}{l}\text { ADUN } \\
\mathbf{L}(\underline{M})\end{array}$} & \multicolumn{4}{|c|}{ Uraniu concentrations ( $p p x)$} \\
\hline & & $\begin{array}{c}\text { First } \\
\text { uranium } \\
\text { scrub }\end{array}$ & $\begin{array}{l}\text { Second } \\
\text { uranium } \\
\text { scrub }\end{array}$ & $\begin{array}{l}\text { Nitrate } \\
\text { waste }\end{array}$ & $\begin{array}{l}\text { Final } \\
\text { scrub }\end{array}$ \\
\hline S22 & 0.20 & 2530 & 396 & 121 & 10 \\
\hline s23 & 0.15 & 1116 & 617 & $49,84,47$ & 21 \\
\hline S24 & - & - & - & $\cong 7$ & 10 \\
\hline s25 & 0.15 & - & 456 & 83,80 & 5 \\
\hline S31 & 0.25 & - & - & 60 & - \\
\hline s32 & 0.25 & - & - & 95 & - \\
\hline S33 & 0.25 & - & - & 52 & - \\
\hline$\$ 38$ & 0.20 & 3450 & 870 & 65 & 10 \\
\hline s39 & 0.23 & 2650 & 1100 & 104 & 4 \\
\hline S41 & 0.10 & - & - & 30,19 & - \\
\hline$\$ 48$ & 0.23 & $\mathbf{a}$ & $a$ & 38,40 & - \\
\hline$S 49$ & 0.20 & $\mathbf{a}$ & $a$ & 41,42 & - \\
\hline 5.53 & $0.2 \mathrm{C}$ & $\mathbf{a}$ & $\mathbf{a}$ & 47 & 0.2 \\
\hline 45 & 0.25 & 770 & 435 & 42 & 5 \\
\hline H6 & 0.25 & 770 & 216 & 13 & 5 \\
\hline
\end{tabular}


Table 3. Uranium concentrations in aqueous streams from amine regeneration for varylng flowsheet conditiong

Solvent flow: Usual1y 0.4 licer/min of 0.4 M Amberlite LA-2 In diethylbenzene

Uranium recovery scrub: one contactor with $\mathrm{h}_{2} \mathrm{O}$ flow of $60 \mathrm{~cm}^{3} / \mathrm{min}$ Final scrub: $\mathrm{H}_{2} \mathrm{O}$ flow of $3.0 \mathrm{~cm}^{3} / \mathrm{min}$

\begin{tabular}{|c|c|c|c|c|c|c|}
\hline \multirow[b]{2}{*}{$\begin{array}{l}\text { Run } \\
\text { r: umber }\end{array}$} & \multirow{2}{*}{$\begin{array}{l}\text { ADUN } \\
\text { urantum } \\
\text { (M) }\end{array}$} & \multirow[b]{2}{*}{$\begin{array}{c}\text { Anl ne regeneracton } \\
\text { conditions }\end{array}$} & \multicolumn{4}{|c|}{ Uranium concentrations (ppm) } \\
\hline & & & $\begin{array}{l}\text { Urantum } \\
\text { scrub }\end{array}$ & $\begin{array}{l}\mathrm{NO}_{3}- \\
\text { waste }\end{array}$ & $\begin{array}{l}\text { PIItered } \\
\mathrm{NO}_{3}-\text { waste }\end{array}$ & $\begin{array}{l}\text { Final } \\
\text { scrub }\end{array}$ \\
\hline \multicolumn{7}{|c|}{ Complete regeneration } \\
\hline $\begin{array}{l}\text { SO1 } \\
\text { SO2 } \\
\text { SO3 }\end{array}$ & $\begin{array}{l}0.70 \\
0.25 \\
0.20\end{array}$ & $\begin{array}{l}\text { Excess } \mathrm{NaOH}-\mathrm{Na}_{2} \mathrm{CO}_{3} \\
\text { Excess } \mathrm{NaOH}-\mathrm{Na}_{2} \mathrm{CO}_{3} \\
\text { Excess } \mathrm{NaOH}-\mathrm{Na}_{2} \mathrm{CO}_{3}\end{array}$ & $\begin{array}{r}13200 \\
2600 \\
1650\end{array}$ & $\begin{array}{r}3600 \\
600 \\
300\end{array}$ & $\begin{array}{l}- \\
600 \\
300\end{array}$ & $\begin{array}{r}8 \\
10 \\
80\end{array}$ \\
\hline \multicolumn{7}{|c|}{ Partial regeneration } \\
\hline $\begin{array}{l}\text { S05 } \\
\text { S06 } \\
\text { SO7 } \\
\text { S08 }\end{array}$ & $\begin{array}{l}0.20 \\
0.20 \\
0.15 \\
0.15\end{array}$ & $\begin{array}{l}\text { NaOH only } \\
\text { NaOH only } \\
\text { NaOH on'y } \\
\text { NaOH only }\end{array}$ & $\begin{array}{l}1800 \\
1480 \\
1430 \\
1520\end{array}$ & $\begin{array}{r}46 \\
60 \\
56 \\
150\end{array}$ & $\begin{array}{c}28 \\
70 \\
41 \\
72,110\end{array}$ & $\begin{array}{l}50 \\
33 \\
32 \\
60\end{array}$ \\
\hline \multicolumn{7}{|c|}{ Partial regeneration } \\
\hline$\$ 11$ & 0.10 & $\mathrm{NH}_{4} \mathrm{OH}$ only & 1320 & - & - & $1]$ \\
\hline$\$ 12$ & 0.05 & $\mathrm{NH}_{4} \mathrm{OH}$ only & - & 155 & 21 & - \\
\hline $\mathrm{S} 13$ & 0.15 & $\mathrm{NR}_{4} \mathrm{OH}$ only & - & 12 & 12 & - \\
\hline $\begin{array}{l}\text { S14 } \\
\text { S15 }\end{array}$ & $\begin{array}{l}0.20 \\
0.20\end{array}$ & $\begin{array}{l}\mathrm{NH}_{4} \mathrm{OH} \text { only } \\
\mathrm{NH} / \mathrm{OH} \text { only }\end{array}$ & $\begin{array}{l}- \\
-\end{array}$ & $\overline{10}$ & $\begin{array}{l}7 \\
6\end{array}$ & $\begin{array}{l}58 \\
62\end{array}$ \\
\hline \$19 & 0.15 & $\mathrm{MH}_{4} \mathrm{OH}$ only & 588 & 20 & 17 & 56 \\
\hline
\end{tabular}


nitrate feed is usually added batchuse before the resin loading is started. Additional water is added to the ADUN in the form of uranium scrubs from the amine regeneration syst $=m$ and wash solution from loaded resin. For a batch addition of uranyl nitrate and a bitch loading of resin, the amount of $\mathrm{UO}_{2}{ }^{2+}$ is controlled by the run conditions (initial ADUN and resin present), and only the $\mathrm{NO}_{3}{ }^{-}$and water are controlled as independent variables. High loadings of uranium on the resin require low $\mathrm{NO}_{3}^{-} / \mathrm{U}$ mole ratios (FIg. 4) for a sufficient time to allow approach to equilibrium. Since the minimum times are greater than $1 \mathrm{hr}$, there is little advantage to using large $\mathrm{NO}_{3}^{-}$removal rates to adjust the $\mathrm{NO}_{3}^{-} / \mathrm{U}$ ratio in short times. Close control of water removal is also of no importance because chis removal has no effect on the $\mathrm{NO}_{3}{ }^{-} / \mathrm{U}$ mole ratio.

\subsection{Uranium Inventcry}

The rate of uranfum removal for a system with a single batch resin loading contactor is high initially but approaches zero as loading is completed. For the first $70 \%$ of the uranium loaded, the ADUN leaving the loading contactor is approximately at equilibrium inth the resin, and the rate of uranium loading depends on the inlet ADUN flow rate, uranium concentratio 1, and $\mathrm{NO}_{3}^{-} / U$ ratio. Both the ADUN flow rate and the uranium concentration are limited at the start since the lignt, :ijugogen-form resin can be easily paciked against the exit screen of the loading contactor. Because of these complex relationships and requirements, attempts to match a continuous uranyl nitrate feed rate with the uranium removal rate wouid be difficult and unnecessary. Addition of 
uranyl nitrate at a continuous, corstant rate over a period of about 2 hr could be used to mininize the uranium inventcry.

The routine procedure for the engineering-gcale resin loading has been batch additions of uranyl nitrate prior to resin loading. The urantu inventory or heel renalning after a batch of resin has been loaded Is usually about equal to that in one batch ( $4 \mathrm{~kg}$ of uranium). This quantf ty is convenient for two zeasons. Mixir 8 of this heel (iNO $_{3}^{-} / \mathrm{U}$ wole ratio of 21.6$)$ with the same amomt of uresis 1 nitrate feed $\left(\mathrm{NO}_{3}^{-} / \mathrm{U}\right.$ of <2.2) results in an average $\mathrm{NO}_{3}^{-} / \mathrm{U}$ mole ratio of 1 ess than 2 . Ratios above 2 are undesirable because they result in increased extraction cf uranium by the andine solvent. At the normal ADUN concentration, $4 \mathrm{~kg}$ of uranium is equivalent to about 70 liters of ADUN. This is a convenient volume to allow all normal prccess operations, including transfer to the dryer, to be perrormed without emptying the ADUN tank. Since transfer, washing, and drying of one batch of resin return about 40 11ters of dilute ADUN to the tank, the system and tank must allow ADUN volume variations of this size even if a continuous feed of uranyl nitrate is used.

The uranium concentrations are determined routinely by measurement of the ADUN density and use of Eq. 4(b) (see Sect. 2.1.2). A special Instrument for in-11ne meapurement of ADUN density was installed, calibrated, and used for both batch and continuous resin loading contactor runs. The response of this instrument is imediate and continuous.

* Dynatro $\mathrm{R}_{\mathrm{C},-10 T Y}$ series denolty celj and converter manufactured by Autosation Products, Inc., Houston, Tex. (see Appendix A). 
Temperature changes in the uranyl nitrate solution are compensated for in the output. The density provides the measurement of uranium concentration by using Eq. 4(b). To date (after 6 months of use), the instrument has proved to be stable, accurate, and sensit:ve to concentrations of $0.001 \mathrm{~g} / \mathrm{cm}^{3}$. The specifications claim applicability to both ilquids and slurries and insensitivity to ambient temperatures, process viscosity, pressure, and flow velocity. The process solution contacts only a 1/2-1n.dian Ut tube which is forced to vibrate like a tuning fork. The vibration, which is measured electronically, changes as the density of the fluid in the tube varies.

\subsection{Water Inventsry}

Since the equilibrium loading $\bar{i}$ urantum is primarily control'ed by the $\mathrm{NO}_{3}^{-} / \mathrm{U}$ mole ratio ( $\mathrm{Fig} .4$ ) over a wide range of $\mathrm{NO}_{3}^{-}$(or urani um) concentrations, close control of the water inventory is not important. For reasons discussed in Sect. 7.1, the usual procedure was to add uranyl nitrate feed batchwise prior to the start of resin loading. Then the evaporator could be operated to remove the water returned as scrub solution from the amine regeneration system plus the ADUN volume equivalent to the amount of uranium loaded. Th1 would total about $(150)(0.2)+40$, or approxdmately 70 liters. For the engineering-scale system, 6-psig steam would give 0.511 ter/min and require about $140 \mathrm{~min}$. In most cases, the evaporator was started early in a run with atout 6-psig steam and then shut off when the ADUN density or volume reached a preselected value. The precipitation of araniun when ADUN having a low $\mathrm{NO}_{3}^{-} / \mathrm{U}$ ratio is heaced above $100^{\circ} \mathrm{C}$ must be considered (see Sect. 5). To avold difficulties from 
sucl. preciptitation, 'speration of the evaporator at $10 \mathrm{~N} \mathrm{NO}_{3}^{-} / \mathrm{U}$ ratios should be avoided and circulation without heat should be used to dissolve any precipitated uraniun.

During batch loading runs, the evaporator was operated to achieve preselected values of ADUN volume or density. During continuous loading runs, the evaporator rate was varied slowly according to the volume in the ADUN tank. The selected volume In the ADUN tank was 35 I1ters; however, variations in the volume occurred from the return of wash water when resin drying rurs were begun.

\subsection{Nitrate Inventory}

The $\mathrm{NO}_{3}^{-} / \mathrm{U}$ ratio of the $\mathrm{ADUN}$ in the resin loading system must $11 \mathrm{e}$ between two limits: that for precipitation of uranium ( 1.45 at $50^{\circ} \mathrm{C}$ ) and that for equilibrium between the ADUN and resin (Fig. 4). The removal of nitrate must be conirolled to avold the pracipitation of uranium, which is undesirable. The required loading of uranium cannot be completed unless the $\mathrm{NO}_{3}^{-} / \mathrm{U}$ ratio is 1.7 or less. This favorable ratio must be maintained for at least $1 \mathrm{hr}$, while 2 hr is a more dependent criterion.

For the engineering-scale system, we chose to use a nitrate extraction rate which usually allowed a run to be completed in about $180 \mathrm{~min}$. A high rate of nitrate extraction is undestrable bersuse repeated "on-off" cycles would be required to keep the ADUN within the $\mathrm{NO}_{3}^{-} / \mathrm{t}$ ratio 11 mits. When the uranium loading rate is $\mathrm{hlgh}$, the $\mathrm{NO}_{3}^{-} / \mathrm{U}$ ratio increases. After the uranium loading rate decreases, the rate of $\mathrm{NO}_{3}^{-}$removil becomes greater than the rate of uranium removal and + !ce $^{2} i_{3}^{-} / U$ ratio decreases. 
The nitrate remoral is terminated before precipitition occurs and the $\mathrm{NO}_{3}{ }^{-} / \mathrm{U}$ ratio increases as loading is completed.

A simple material balance shows that the loading must be nearly complete when the nitrate removal operation is terminated if the $\mathrm{NO}_{3}^{-} / \mathrm{U}$ ratio is to remain below 1.7 . For $4 \mathrm{~kg}$ of uranium and a $\mathrm{NO}_{3}^{-} / \mathrm{U}$ ratio of 1.45, the ADUN contains 17 moles of uranium and 25 moles of $\mathrm{NO}_{3}^{-}$when nitrate removal is stopped. Removal of about 2 molts of uranium increases the $\mathrm{NO}_{3}^{-} / \mathrm{U}$ ratio to 1.7 ; this indicates that Luding must be at least $90 \%$ complete when nitrate removal ceases. If allowances are made for the concentration variations throughout the system, $95 \%$ or greater completion of loading is a more realistic criterion for determining whether the loading can be completed without resuming the nitrate removal operation. The required rate of nitrate extraction can be calculated as follows:

Uranium loaded: $4 \mathrm{~kg}$ or 17 moles

Amount of nitrate in feed $=(17)(2.1)=36$ moles

Nitrate extraction rate $=36 / 180=0.2 \mathrm{~mole} / \mathrm{min}$

This nitrate extraction rate is equivalent to $4 / 3 \mathrm{~kg}$ of uranium per hour.

\subsection{In-Line $\mathrm{pH}$ Units to Measure $\mathrm{NO}_{3}^{-} / 2$ Ratios}

In-line $\mathrm{pH}$ units were purchased irom three major manufacturers and used in the engineering-scale resin loading system. These units had many similarities. Each used a recommended combination of electrodes, temperature compensator 3 , an amplifier at the in-line element, and a panel-mounted indicator with standard outputs (4 to $20 \mathrm{~mA}$ ) to recorders. Additional descriptive det31ls are given in Appendix A. 
The In-line pH units were standardized by measuring the ph values of samples of ADUN with a standard laboratory pH meter and then adjusting the In-line units to lndicate these values. Use of the ADUN as a buffered solution for calibration was found to be much siapler than the addition and removal of standard buffer solutions.

Evaluation of the in-line units showed that each is adequate to meet the resin-loading process requirements. No gross errors were observed. Changes between callbraclons were usually small; in a few instances, corrections of 0.2 to $0.4 \mathrm{pH}$ unt becase necessary after shutdowns of Beveral days to severa- weeks. The Leeds and Northrup system proved to be the most satisfactory since the other two systems displayed minor faults. The Beckman system showed differences of up to $0.2 \mathrm{pH}$ untt from the other two in-line $\mathrm{pH}$ measurements and the iaboratory meter as a result of changes in temperatures and flow rates. The Foxboro system showed slower responses to changes in $\mathrm{pH}$ which appeared to result from channeling of the ADUN flow without complete displacement of the solution In the meter. Also, the Foxboro in-11ne element was much larger and heavier than the other two. The suitability of the seals, electronfc components, and case materials for in-cell radiation exposures has not been evaluated. Any differences in these or other attributes might be more significant than the minor differences mentioned above.

The $\mathrm{NO}_{3}^{-} / \mathrm{U}$ ratios were determined from the $\mathrm{pH}$ measurements by using graphical correlations $(\mathrm{FIg} .5)$. These correlations show that $\mathrm{NO}_{3}^{-} / \mathrm{U}$ rat108 vary only woderately with urantum concentrations and that the determation of uranium concentrations from densities is more than adequate. 
Numerical data in Appendix $D$ show the importance of the final $\mathrm{NO}_{3}^{-} / \mathrm{U}$ ratio and the small effect of uranium (or $\mathrm{NO}_{3}{ }^{-}$) concentration.

\subsection{Experimental Results}

The control and behavior of the ADWN concentrations during resin loading result fron the addition and removal of three components. The ADUN volume is determined by the addition and removal of water. The urantum concentration varies as a result of uranium additions or removals and changes in volume. Changes in the $\mathrm{NO}_{3}^{-} / \mathrm{U}$ ratio arise from the addition or removal of nitrate and uranium (but not vater). The uranium removal rate depends on the ADUN tank $\mathrm{NO}_{3}^{-} / U$ ratio, the resin loading extt (equilibrium) $\mathrm{NO}_{3}^{-} / \mathrm{U}$ ratio, and the $\mathrm{ADUN}$ flow rate. The water removal rate is set by the evaporator rate. The nitrate removal rate is set by the rate at which caustic is introduced to the regeneration cont.actor after the nitrate extraction sysiem has atcained steady state; however, changes in solvent or caustic flow rates result in complex unsteady-state rates. The material balances were used to calculate chese concentrations throughout a typical run (Table 4) and two other runs (Tables 5 and 6 ).

The changes during a run are lllustrated by graphs of ADUN concentrations vs time. In a nomal or typical run (Fig. 14), the intial and final uranim concentrations are approximately the same, with a minfmum ocsurring at some intermediate time. A large volume decrease is required to correspond to the removal of uranium by the resin. The $\mathrm{NO}_{3}{ }^{-} / \mathrm{U}$ ratio starts at an intermediate value (resuiting from the additior. of uranium feed before the run is started) and goes through a maximum as a result of high initial uranium removal rates. 


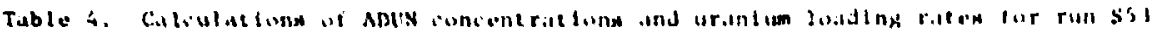

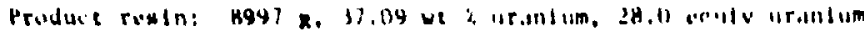

\begin{tabular}{|c|c|c|c|c|c|c|c|c|c|c|c|c|c|c|c|c|}
\hline \multicolumn{2}{|c|}{ rime } & \multirow{2}{*}{$\begin{array}{l}\text { ADLN } \\
\text { Volune } \\
\text { (1itur }\end{array}$} & \multirow{2}{*}{$\begin{array}{l}\text { data } \\
\text { cunc: } \\
(\underline{y})\end{array}$} & \multirow{2}{*}{$\mathrm{pH}$} & \multirow{2}{*}{\multicolumn{3}{|c|}{ 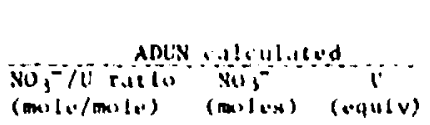 }} & \multicolumn{2}{|c|}{ 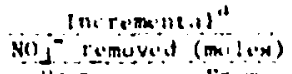 } & \multicolumn{3}{|c|}{ Kandn Jind!ng - } & \multirow{2}{*}{\multicolumn{2}{|c|}{ 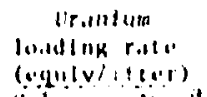 }} & \\
\hline Clwik & $\begin{array}{l}\text { Run } \\
(\operatorname{lol})\end{array}$ & & & & & & & $\begin{array}{l}\text { From } \\
\text { Pluses }\end{array}$ & $\begin{array}{l}\text { Frum } \\
\text { pill }\end{array}$ & $\begin{array}{l}\text { Findi } \\
\text { pik }\end{array}$ & $\begin{array}{l}b \times 11 \\
\text { sio } 1-11\end{array}$ & 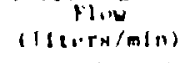 & & & Inirumentib! & Thinl \\
\hline iY00 & -15 & 138 & 0.41 & 2.75 & 1.80 & 50.9 & 56.6 & - & - & - & $\therefore 6$ & - & $0.12 \mathrm{~h}$ & . & - & - \\
\hline $09: 0$ & $\vdots$ & $: 19$ & 0.405 & 2.75 & 1.80 & 50.7 & $\therefore 6.1$ & 0 & U.: & 0.4 .4 & $\therefore 5$ & 1.4 & 11.111 & 0.120 & $1.1 \%$ & $1.1:$ \\
\hline $04 \div 0$ & 25 & 112 & 0.38 & 2.55 & $1 .+1$ & $\therefore 7.9$ & 50.2 & 1 & $\therefore . B$ & 1.111 & $\therefore 4$ & 1.4 & 0.076 & 45 & $\mid .61$ & \# \\
\hline 1000 & is & $1: 4$ & 0.37 & $\therefore 5$, & 1,41 & $\therefore \therefore .1$ & $\therefore 4$ & 1.7 & 1.4 & 1.14 & $\therefore 35$ & 1.4 & 0.13 sh & 0.0112 & $\therefore m_{0}$ & $1, \therefore 4$ \\
\hline $10: 0$ & his & 118 & 0.36 & $\therefore 57$ & 1.41 & 011.11 & $\therefore 2 \therefore$ & 1.7 & 1.1 & 1.21 & $\therefore$ is & 1.4 & 0.0his & $11.0 \mathrm{sh}$ & $\therefore \therefore 7$ & 4.40 \\
\hline $10 \div 0$ & x5 & $11:$ & 0.30 & 2,61 & 1.911 & 36.1 & 60.9 & 1,1 & 1.7 & 1.11 & 2.1 & 1.4 & $0.16)_{1}$ & $11.11 \mathrm{hl}$ & $\therefore \therefore 1$ & 12.14 \\
\hline 1100 & 105 & 106 & v. 10 & $\therefore B H$ & $1 . \mathrm{KA}$ & 15.7 & 14.2 & 1.1 & $\therefore \therefore$ & 1. in & $\therefore 1$ & 1.9 & 0 , Ithen & 1. 16h: & $\therefore 1$ & 14.82 \\
\hline 1120 & $1: 5$ & 100 & 0.13 & $\therefore 75$ & $1,8:$ & 11.4 & 15.0 & 1.1 & 4.11 & 1.74 & $\therefore 1$ & $811 \times .4$ & $(1,1) i b ;$ & $11.13 \mathrm{~K}$ & 2.20 & $(1,1) 2$ \\
\hline $11 \div 0$ & 145 & 44 & o. : i & $\therefore N 7$ & 1.7 & $2 H . n$ & $3 \therefore y$ & 3.7 & $1 . h$ & $\therefore 7 H$ & 1.155 & $\therefore 4$ & 0.0 .1 & $11.11 \mathrm{sin}$ & 1.11 & ניו , ו'י \\
\hline 1200 & 105 & 88 & J. & 1.00 & 1.64 & 25.4 & 311.8 & 3.1 & $\therefore 7$ & $\therefore 91$ & $1 . H$ & $\therefore .4$ & $0,0 \geq 1$ & 11.11:? & $\therefore 16$ & $\therefore \therefore 11$ \\
\hline 1220 & 18 ; & 8. & 0.36 & 1. IH & 1.26 & $\therefore \therefore$ & 29.8 & 3,7 & 1.: & 1.09 & $1.0 \mathrm{r}$ & $\therefore y$ & 0.1124 & $0.11 \div 1$ & $\therefore 2$ & $\therefore 4,11$ \\
\hline $1 \because \div 0$ & 20 & 70 & 0.17 & 1. 10 & $1,4.4$ & $\therefore O . H$ & 28.1 & 1.9 & 1.9 & 3.21 & 1.5 & $\therefore, 4$ & 0.111 & $0.31,0$ & 1.40 & $\therefore h .11$ \\
\hline 1300 & 2 & .0 & 10.41 & 3. 10 & 1.65 & 20.8 & $2 \mathrm{H.} 7$ & 0 & 0 & 3.25 & $1 . \therefore A$ & $\therefore .4$ & $0.008 \mathrm{~B}$ & (1.01:: & 1.18 & 21,41 \\
\hline $13: 13$ & $\therefore$ & 30 & $0 .: 11$ & 3.1. & 1.65 & $2(; .3$ & 24.11 & 11 & 0.5 & 3.25 & 1.64 & $\therefore 4$ & 0.006 & $0, \mathrm{JUH}$ & 11.78 & $\therefore H$, HY \\
\hline $1 ; 30$ & $33=$ & 70 & 0.60 & 3. is & 1.65 & 0.1 & 24.0 & 13 & () & 1.31 & $1 \therefore 0$ & $i 0.4$ & 0.001 & $0.00 \%$ & 1.70 & $30,{ }^{3}$ \\
\hline
\end{tabular}

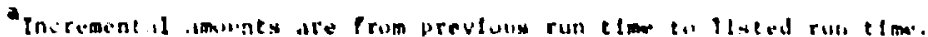




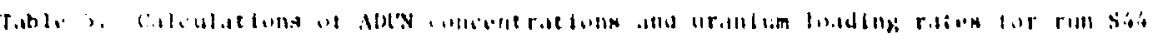

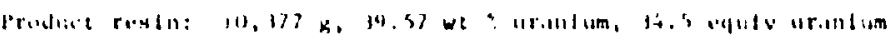

\begin{tabular}{|c|c|c|c|c|c|c|c|c|c|c|c|c|c|c|c|c|}
\hline \multirow{2}{*}{ clank } & \multirow{2}{*}{ metin } & \multicolumn{3}{|c|}{ 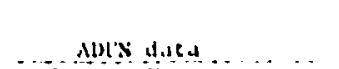 } & \multicolumn{3}{|c|}{ 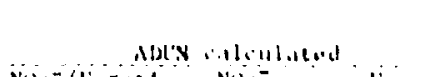 } & 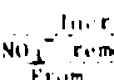 & \multicolumn{2}{|c|}{ I!n rumnent!" } & k. & & \multicolumn{2}{|c|}{ 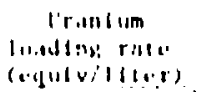 } & \multicolumn{2}{|c|}{ 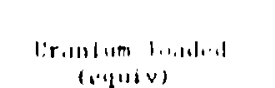 } \\
\hline & & (iatera) & (w) & 听 & $(m a 10 \cdot(m+10)$ & $(3 k, 1, \cdot 4)$ & $(\log u(v)$ & thing & pil & 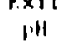 & No, $1,-11$ & $(111,1+1 / m(n)$ & Cial 1 & Avi.." & 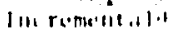 & $T(1,1)$ \\
\hline $04: 0$ & -60 & 100 & $0.4 !$ & 3.it & !. h0) & $12 . \mathrm{K}$ & $\therefore 1.11$ & - & - & - & $\therefore n$ & 1.4 & $0.11 \mathrm{k}$ & - & - & - \\
\hline $08 \div 0$ & 10 & $10:$ & 10. 18 & 3.1 & 1.60 & 31.11 & 14.4 & 1.1 & $1 . x$ & 1.1 & $\therefore 5$ & 1,9 & $0.11 \%$ & $0.1: k$ & $\therefore x i$ & $\therefore \times 1$ \\
\hline $0 y 00$ & $11)$ & lun & $0.1:$ & 1.111 & I. $i 1$ & $\therefore A, H$ & 11.4 & $\therefore i$ & $\therefore$ & $1 . . " 5$ & $\therefore \because 40$ & 1.9 & 0.1914 & $0.1:$ & atill & 1.11 \\
\hline $10 \% 20$ & w & 48 & 0.24 & 1.102 & 1.12 & $\therefore$, & $\therefore x .$. & $\therefore:$ & $\therefore 1$ & $1 . \therefore$ & $\therefore \therefore$ & 1,4 & 1).11h: & 0.04 & $1,6 !$ & 111. :" \\
\hline $14 \div 0$ & $?$ & 40 & 10.27 & 1.03 & $1 . \cdots$ & $\therefore 1$. & $\therefore .1$ & $\therefore 1$ & $1 . \therefore$ & $\therefore$ & $\therefore 15$ & 1.4 & 0.1170 & $0.0 \% \mathrm{~h}$ & $\therefore \times 4$ & 13,6, \\
\hline :000 & 90) & 8: & 0.2, & 1.1 & 1.84 & $1 i .1$ & :11.' & $\therefore:$ & 1.4 & $1 . n$ & $\therefore 1$ & 1,4 & $0.1 \mathrm{hth}$ & $0,06,4$ & $\therefore$ SH & $10 . .6 t$ \\
\hline 1020 & 110 & $\therefore$ & $0.2:$ & 1.16 & 1.05 & 1.1 & $1 i .11$ & $\therefore 1$ & 1.2 & 1.1.: & $\therefore 1$ & 1.4 & 0.015 & a.oks & $\therefore \therefore i$ & $! x \cdot 11$ \\
\hline $10+4$ & 10 & non & 0.21 & 1.03 & 1.1, & $1 \therefore 1$ & 13,4 & $\therefore i$ & $\therefore 11$ & $\therefore$. & $\therefore 01$ & $\therefore 4$ & 11.011 & 0,0 & $\therefore 11$ & $\therefore 3.10 n$ \\
\hline 1100 & 130 & in & 0.18 & 1.11 & $1 . \therefore$ & 4.1 & $111 . .$. & $\therefore i$ & 3.10 & $\therefore 4$ & 1.4 & $\therefore 4$ & 0.2115 & $11,11.21$ & $\therefore \therefore$ & $\therefore, 11$ \\
\hline 1120 & 170 & 50 & 0.17 & 1.30 & 1.n: & 11.4 & 4,5 & $\therefore 4$ & $\therefore 1$ & 3.1 & $1.7 H$ & $\therefore 4$ & $0,(1)$ & 0,01, & $1 . \therefore 1$ & $\therefore(1, x !$ \\
\hline 11.00 & $: 10$ & $\because 2$ & 0.165 & 1.24 & $1, n 0$ & 5.5 & $n .4$ & 1.9 & $1, \therefore$ & 1.. & $1 .:$ & $\therefore 4$ & 0.01010 & 0,011 & $1 . .1$ & . \\
\hline $1: 00$ & 210 & $\therefore 3$ & $0.1:$ & $1 . .1$ & $1 \ldots$ & $\checkmark .1$ & $D . H$ & 1.9 & $0 .:$ & 1.1 & $1.6 i$ & $\therefore, 4$ & $0.111 . !$ & 0.0111 & $1.11 \mathrm{~K}$ & . \\
\hline$(4)(4)$ & $\therefore 70$ & $\therefore$ & 11.11 & $1, \therefore 1$ & $1, \ldots$ & 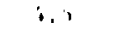 & $\because . "$ & 11 & 11,1 & 1.15 & I. & $\therefore "$ & $0,(11) ;$ & $\mathrm{N},(101) \mathrm{H}$ & $\therefore 11$ & $11 .$, \\
\hline 15190 & 340 & $\therefore$ & 0.11 & 1.34 & $1 . n 0$ & $\therefore, 1$ & 3.1 & 11 & 11.1 & 1.14 & I. ni) & $\therefore 4$ & 11 & 14,0101 & 1,30 & 14.21 \\
\hline
\end{tabular}




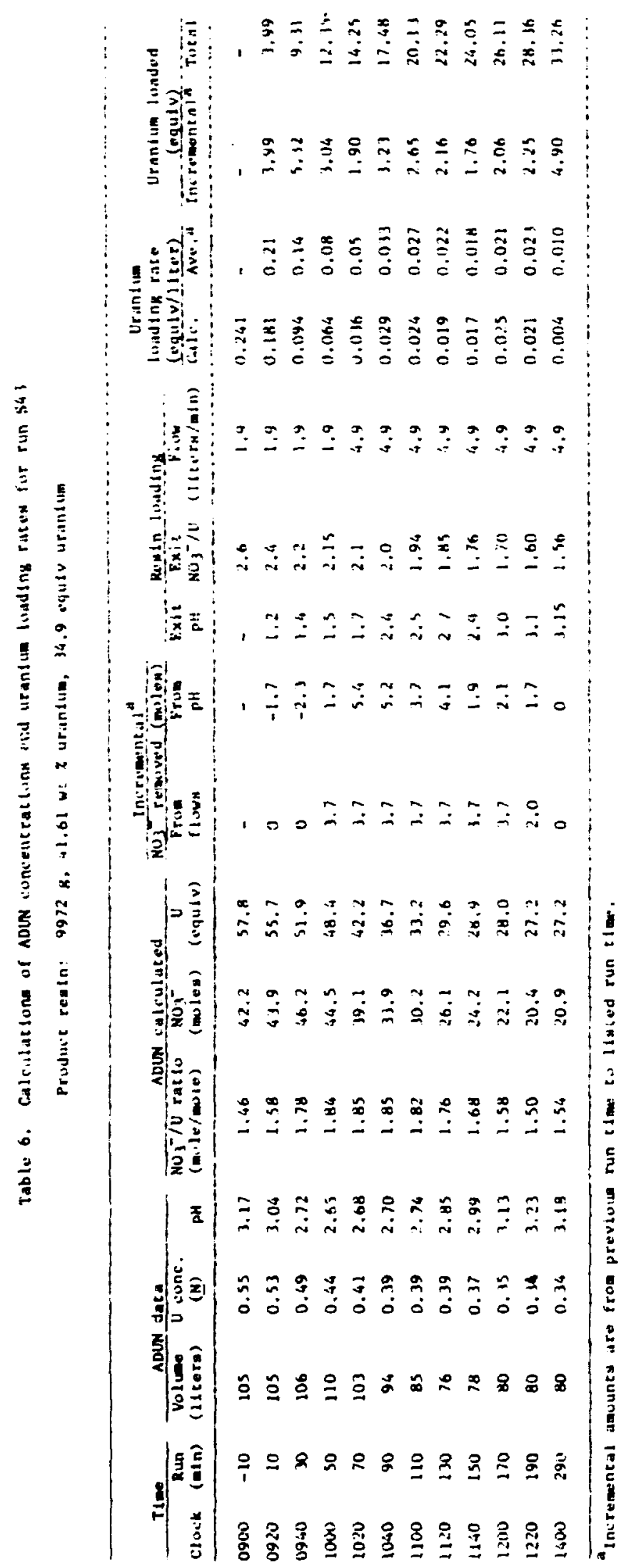




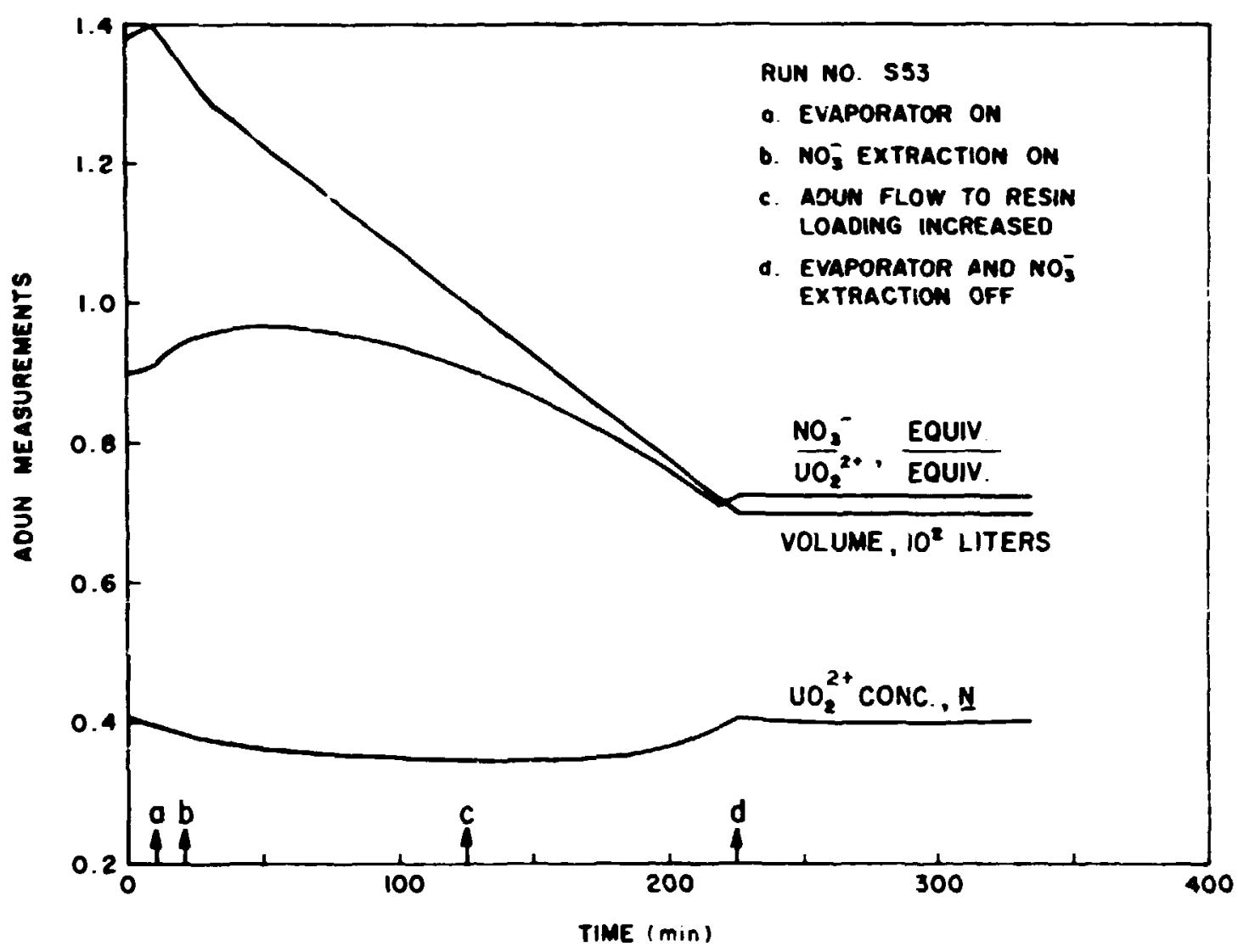

F18. :4. Acid-deficient uranyl nitrate concentrations and volumes for a reference batch loading run. 
The end-of-campaign loading procedure (discussed in more detail in Sect. 7.6) gives different curves (Fig. 15). The uranium concentzation is reduced to a low final value by using a longer run time. The initial $\mathrm{NO}_{3}{ }^{-} \mathrm{U}$ ratio is low as a result of small additions, if any, of uranium feed bafore the run. The final ADuN volume is the minimum that allows continued operation.

The desired condizlons for operation wth continuous rasin loading (the Higgins column) are constant inventories of nitrate and uranium. With these inventories constant, the $\mathrm{No}_{3}^{-} / 0$ ratio will be constant and the uranium removal and nitrate removal will equal the feed rates. The water inventory (ADUN volume) will vary as a result of returns of wash water from resin drying, but this should not change the $\mathrm{NO}_{3}^{-} / \mathrm{U}$ ratio. Values for one period of operation with the Higgins colunn are shown in Fig. $i \epsilon$.

The measured ADUN values and material balance calculations used in preparing Figs. 14 and 15 are listed in Tables 3-5. The uranium concettrations were obtained frum density measurements and Eq. (4b). The pH values from the in-line instruments are used with Fig. 5 and similar plots to estimate $\mathrm{No}_{3}^{-} / \mathrm{L}$ ratios. The $\mathrm{ADUN}$ volumes are interpolated from several measurements performed during the runs and from the known evaporator and scrub rates. The nitrate removal rates obtained from the difference in calculated amounts of nitrate are in reasonable agreement with those calculated from the caustic regeneration rate.

Urantum loading rates can be calculated from the ADUN concentrations and flow rates for the resin loading contactor. Integrating these rates or delermining the differences in ADUN uranium inventory gives 80 to $110 \%$ 
ORWL JW6 77-3e0 RI

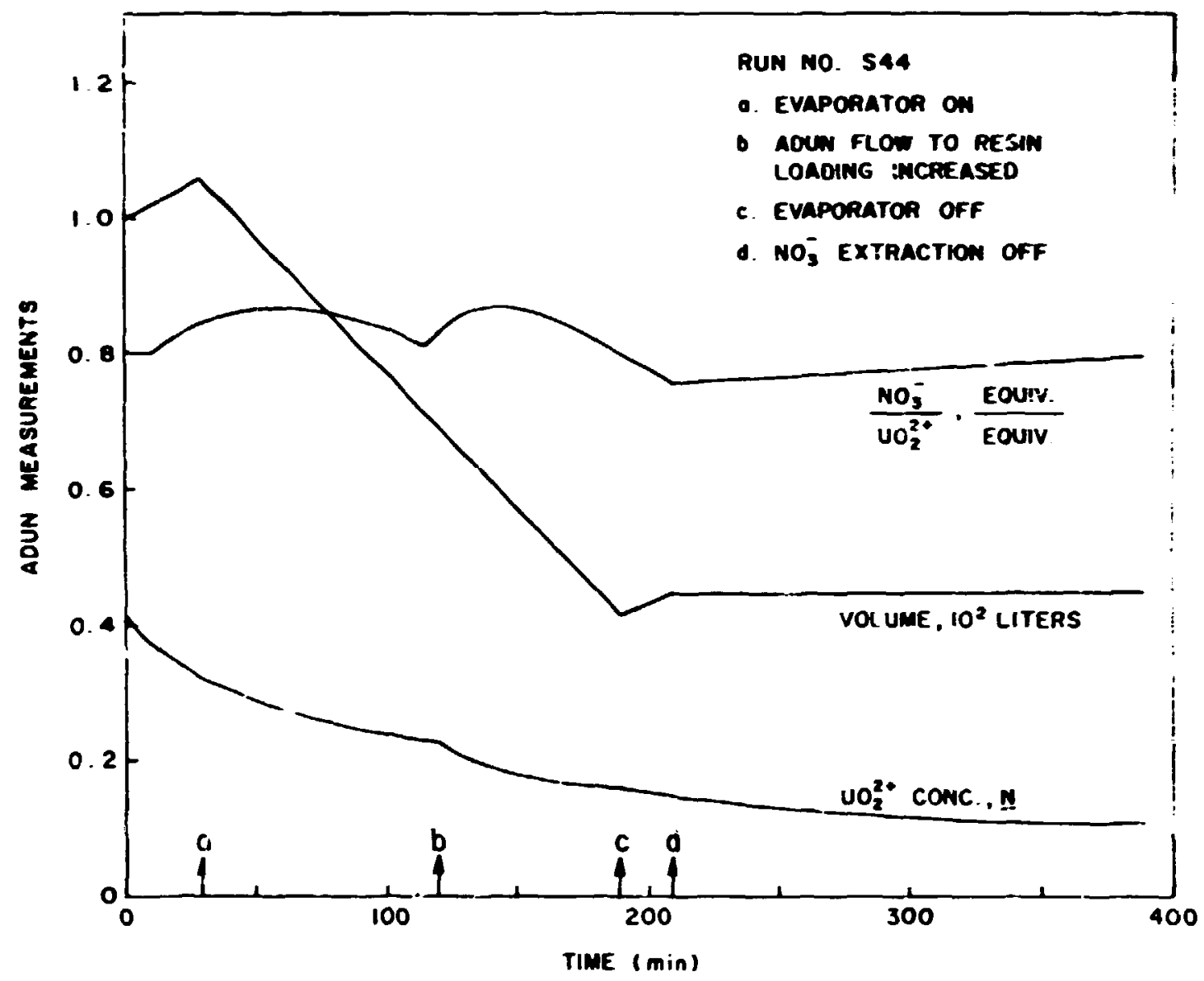

Fig. 15. Acid-defficient uranyl nitrate concentrations and volumes for an end-of-campatign loading run. 
canc owe 17-309A1

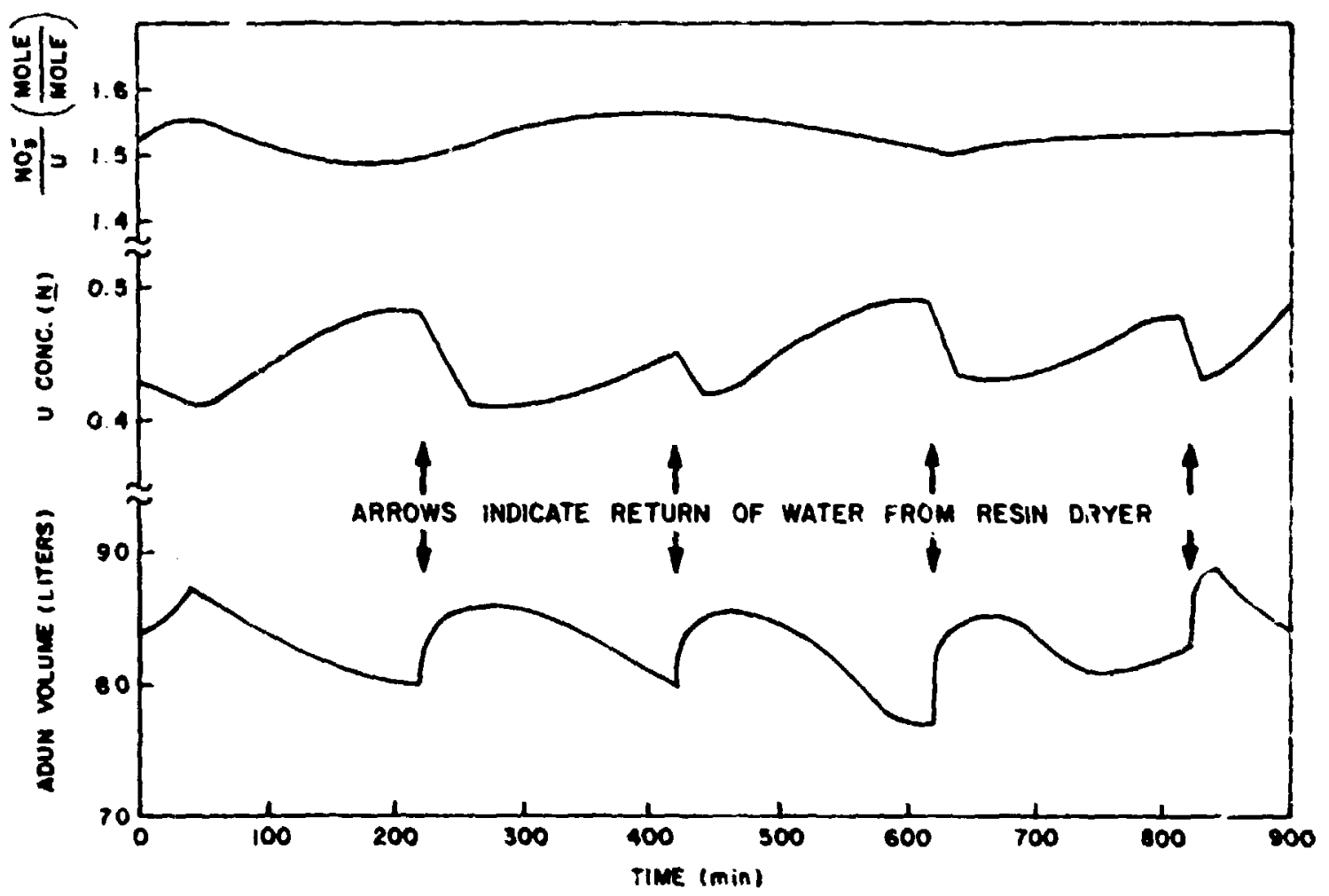

FIg. 16. Acld-deficient uranyl nitrate concentrations and volumes for a continuous (Higgins column) loading run. 
of the amount of uranium shown by analyses of dried resin. These are reasonable checks when one considers the many approximations in both measurements. The uranium material balances generally show that 50 to $75 \pi$ of the uranium has been loaded when the ADUN flow to the loading contactor is increased; this observation is consistenc with the equilibrium data (Fig, 4). The calculated uranium loading rates near the end of the runs are of poor accuracy since they depend on pH differences of less than 0.1 unit.

The engineering-scale resin loading system was operated for 54 batch loading runs and 22 batches of resin from the continuous (Higgins) contactor tests to prepare more than $600 \mathrm{~kg}$ of drfed, uranium-loaded resin. Some of the results are tabulated in Appentix D. This program was completed without a single fallure of the process outlined in the chemical flowsheet or any evidence of inability to control the conditions dictated by the flowsheet. Every batch of resin was processed through the desired loading cycle; several runs which were interrupted by mechanical problems (e.8., a leak of the ADUN solution cr an instrument failure) were simply shut down and then resumed after mechanical repairs had been completed. The only incompletely loaded resin batches resulted from tests of short duration, end-of-uranium batch conditions, or other special circumstances which explain the resulcs. One batch loading run per 8-hr day was made for $\mathbf{s 1 x}$ successive workdays (runs $\$ 29$ through S34) to demonstrate operation of the complete engineering-scale system. The fallure of the initial Higgins column cests stemmed from mechanical problems ${ }^{7}$ which have no significance for the batch resin loadiug flowsheet. 


\subsection{End-of-Campaign Loading Procedures and Results}

For ${ }^{233} \mathrm{U}$ recycle, the ${ }^{233} \mathrm{U}$ destined for use with different isotopic compositions or in different reactors would have to be refabricated in separate campaigns. Thus the uranium remaining at the end of the last resin loading run for a campaign woul $\dot{i}$ have to be removed from the system and subsequently shipped or stored. Tests were made to demonstrate that special loading cuns could be made to minimize this f!nal inventory. In these tests, a resin volume was selected that would jeave less than $1 \mathrm{~kg}$ of uranium inventory after a full loading of the resin. The rate of nitrate extraction was reduced and longer run times were used sis that resin loading could be carried out to low uranium concentrations. The minimum ADUN volume was about 40 liters during resin loading. Almost half of this volume is in the loading contactor. After loading and drying had been completed, nitric acid was added to Increase the $\mathrm{NO}_{3}^{-} / \mathrm{U}$ ratio to about 2 . The ADUN was concentrated to the minimum volume that allowed nomal operation of the evaporator. Using these procedures, a 7.3-11ter batch of resin was loaded to a normal uranium content (run S41), leaving $0.8 \mathrm{~kg}$ of uranium in solution. A normal size batch of resin was loaded to a slightly low uranium conterit (run S44, Table 4), leaving $0.5 \mathrm{~kg}$ uranium in solution. The $\mathrm{NO}_{3}^{-} / \mathrm{U}$ ratio increased after the nitrate extraction had ceased (see discussion in sect. 7.3). A short period of additicnal nitrate e.:traction and a longer run time would probably have loaded sufficient additional urantum to achleve the noraml uranium content. These results indicate that the proposed end-of-campaign procedures are adequate. 


\section{EFFECTS OF FEED RESIN VARIABLES}

The variables for the feed resin have only small effects on the operation of the engineering-scale resin loading system. Nimerical results are tabulated in Appendix D. The amount of uranium loaded per unit volume of feed resin is about $20 \pi$ greater for Amberlite IRC-72 than for Duolite C-464. The size and shape of the resin particles can result in $\pm 5 \%$ variations in capacity as a result of their effects on packing density or void volume between particles. The loading and nitrate extraction are controlled by the concentrations of the ADUN; therefore, the variations in resin capacity do not require any control measurements or actions.

A 50- $\mu$-rated filter is used to remove solids from the ADLN. The Amberlite IRC-72 has fine resin particles when received, but most of these are remojed by wet and dry screening in a resin feed preparation facility. One lot of the Duolite C-464 released small chips or pieces apparently generated by erosion of the surface of the resin spheres. The $0.6-\mathrm{ft}^{2}$ filter cartridges in the engineering-scale system filter was usable for many runs with Amberlite IRC-72 resin but showed significant plugging after several runs with silis lot of Duolite C-464 resin. Plugging was not noticeable in later runs made with another lot of Duolite C-464. Variations in particle size or shape of the resin feed are carried through to the uranium-loaded product but do not have any effect on the mode in which the engineering-scale resin loading system must be operated. 
9. MECANITCAL COMPONENTS, RESIN TRANSFERS, AND EQUTPMENT SELECTION

This section will briefly report results and observations from operation of the engineering-scale resin loading systcm which do oct fit in elsewhere but need to be considered during the design of a rewoteiy operated facility. The engineering-scale resin loading systen is not a prototype systen; that Is, sowe of the components are either not optian or are unsultable for a remotely operated ptlot plant.

\subsection{Pumps and Liquid Metering}

The ADUN pump is a standard type of canned-rotor centrifugal pump* wth graphite bearings. A simflar pum with special aluminum oxide bearings was reserved for use in case the graphite bearings presented problems; however, no difficulties have been encsuntered. The graphite bearings would probably have a longer life under normal process conditions; on the other hand, the aluminum oxdde bearings would allow pumping of hot, nttric acid solutions at concentrations which would attack the graphite.

The only special problem with metering the ADUN solution Involved the effects of entrained resin fines. These fines were rewoved by use of standard filter cartridges of $25 \cdot \mu$ or $50-\mu m$ rating between the ADUN puwp and the flow metering and control instrumentation. The amounts of fines were small for Amberlite IRC-72 resin processed in the resin feed preparation faclity, and use of the resin for ten runs did not decrease the filter flow capacity.

$\star$

Chempurp sodel SF-3/4-3/4S. 
The nitrate extraction solvent was metered and pumped by cam-operated Teflon bellows pumps ${ }^{\star}$ using gage glasses with stopwatches to check the flow rates. These pumps, which were initially selected for the prototype SOLEx equipment, ${ }^{11}$ were completely trouble-fret. However, the Teflon bellows and the gage glass and cam adjustment for flow control wight not be acceptable for remote operation.

\subsection{Temperature Control}

The nitrate extraction system was provided with a hot-water temperaturf sontrol system carefully engi neered to meet SOLEX process requirements. 11 While temperatures of 40 to $60^{\circ} \mathrm{C}$ improve phase separation and provide more favorable kinetics for resin loading, the temperatures are much less critical than for SOLEX. Two heat exchangers, one for the ADUN flow from the pump and one for solvent to the caustic regeneration contactor, would provide adequate control for resin loading.

\subsection{Resin Transfers}

The resins in either the hydrogen- or uranlum-loaded forms can be transferred very easily by a small excess of water over that present in a settled bed, or by alr after drying to remove all surfac's liquid. Gas or liquid pressures of less than 10 psig were used for routine transfer through $20 \mathrm{ft}$ of $1 / 2-1 \mathrm{n}$. -ID tubing, Including numerous bends and ball valves. However, there are two situations in which transfers can be 1mpossible and these must therefore be avoided. If liquid is drained from between the resin particles, the surface films of liquid hold the

\footnotetext{
* Research Appliance Co. Micro Bellows pumps.
} 
particles together and restrict movement. Therefore, wet resin flows very pootiy as compared with either dry resin or resin in an excess of solution.

The second situation that should be avoided is setrling or pecking of resin into a line since any restriction, even a very minor one, may make resumption of flow impossible. To avoid this problen, all resin reservoirs were provided with valves as close to the reservoir as posstble for bottom connections. All transfers of resin were followed by a volume of liquid or gas to empty the transfer lines of resin particles. The characteristics of a packed bed of resin are such that high pressure drops rannot overcome the effects of the flow restriction on a line. If no restriction exists, fluid flows between the resin spheres and refluidizes the line starting at the leading edge of the packed resin. If a restriction does exist, the resin packs tighter at the point of restriction and high pressures can cause formation of a plug -- perhaps from deformation and locking together of the porous plastic spheres. One special example of a restriction is the bed of resin in the batch loading contactor. If the ADUN flow is shut of $\mathrm{w}$ thout closing the valve at the bottom of the contactor, resin settles into this line. Once this has settled completely, the weight of the resin in the contaccor restricts the return of resin from the line. Consequently, solution pressure is not effective for return of the resin into the loading contactor against the settled bed. For this reason, the shutoff valve near the contactor must be closed first before the pump is shut off, or the flow is otherwise interrupted. 


\section{DISCUSSION AND CONCLUSIONS}

A complete engineering-scale system was inscalled and tested for the uranium-loading part of a resin-based preparation of HTGR fuels. The system was full scale ( $4 \mathrm{~kg}$ of uranium per batch) for the Hot Engineering Test Program (HETP) facility plani.ed for the Thorium-Uranium Recycle Facility. The procedure that was develcped requires about $4 \mathrm{hr}$ of solutionresin contact time for loading and less than $4 \mathrm{hr}$ for the associated operations including resin drylng. The engineering-scale system with alternate use of two batch loading contactors would have the capacity for a commercial recycle facility ( $24 \mathrm{~kg}$ of ${ }^{233} \mathrm{U}$ per day), and would not require scale-up.

The engineering-scale resin loading system devel sped and tested the concepts critical to meeting the requirements for remote operation with ${ }^{233} \mathrm{U}$. It was operated with natural uranium and was not a prototype system. Manually operated or observed valves, fluid metering, and fluid control devices were used since the resin loading process does nci impose any special requirements on these components.

The uranium feed to a resin loading system is uranyl nitrate containing some excess nitric acid. The uranium is removed from solution by exchange of $\mathrm{UO}_{2}{ }^{2+}$ for $\mathrm{H}^{+}$in carboxyllc acid cation exchange resins. The reference contactor is a 5-in.-1D fluidized bed with 11-- to 13-1iter bacches of resin. An evaporator spectally designed and fabricated for this system removes the water as condensate containing less than 0.5 ppm of urantum. The nitrate is extracted as nitric acid by an amire solvent with regeneration of the solvent to give a $\mathrm{NaNO}_{3}$ waste solution. The uranium content of this waste amounts to $0.03 \%$ of the total uranium 
loaded on the resin. The solvent extraction equipment was that previously developed for sol-gel processes. 10,11 The optimum water content of dried, uranium loaded resin was found to be 10 to 20 wt $z$. A microwave-heated dryer was installed and tested to provide controlled and uniform drying for this range of water content.

Satisfactory control of the resin-loading system was demonstrated. The resin loading reactions result in both equilibrium and kinetic limitations on the process. The procedures for the engineering-scale resin loading system were chosen so as to allow operation to preselected end points for each batch. The urantum feed ( $4 \mathrm{~kg}$ of uranium per batch) is charged and mixed with about an equal awount of uranium remaining as process holdup between batches. The three removal processes (for $\mathrm{UO}_{2}{ }^{2+}$, $\mathrm{HNO}_{3}$, and $\mathrm{H}_{2} \mathrm{O}$ ) are started approxdmately simultaneously. The evaporator is operated unt 11 the volume of solution is reduced to a predetermined value. The nitrate extraction is operated until in-line $\mathrm{pH}$ instrumentation Indicates that the $\mathrm{NO}_{3}^{-} / \mathrm{U}$ ratio is reduced to a preselected value. The resin loading is continued for about $4 \mathrm{hr}$ until a preselected combination of time and solution $\mathrm{pH}$ has been sarisfied. Although the uranium concentrations could be adequately predicted by material balances, they were confirmed by in-1ine measurements of solution density. This combination of process control procedures has given trouble-free operation and excellent control of the resin loading. The in-line pH and density measurements are dependab!e and of adequate sensitivity. Small modifications nf the loading pricedure allow reduction of the uranium inventory as solution at the end of the special run to less than $1 \mathrm{~kg}$ of urantum. 
Fifty-four batch loading runs were made without a single failure of the process outlined in the chemical flowsheet or any evidence of inability to control the conditions dictated by the flowsheet.

The reference Amberite IRC-72 resin and the alternate Duolite C-464 resin do not require any differences in resin loading conditions. The Duolite C-464 resin has 10 to 207 lower capacities for uranium expressed as either milliequivalents of uranim per gram of dry $\mathrm{H}^{+}$-form resin or as equivalents of uranium per liter of resin.

The engineering-scale resin loading system was also operaced with a 2-in.-ID Higgins type of continuous resin loading contactor in place of the batch contactor. Resin loading was good, with excellent steady-state control of the addition and removal of uranium, water, and $\mathrm{NO}_{3}{ }^{-}$. The demonstrated capacity of more than $1 \mathrm{~kg}$ of uranium per hour indicates that a single, critically safe system could easily load wore than $100 \mathrm{~kg}$ of uranium per day.

\section{REFERENCES}

1. P. A. Haas, HTGR Fuel Vevelopment: Use of U03 to Load Cation Exchange Resin for Microsphere Preparation, ORNL/TM-3817 (September 1972).

2. P. A. Haas, "Loading a Cation Exchange Resin with Uranyl Ions," U.S. Patent 3,800,023 (Mar. 26, 1974).

3. P. A. Haas, HTGR Fuel Development: Loading of Uranium on Carboxylic Acid Cation-Exchange Resins Using Solvent Extraction of Nitrate, ORNL/TT-4955 (September 1975).

4. J. H. Shaffer et al., GCR-75/7, GCR-75/13, GCR-76/14, and GCR-76/16 (internal GCR program reports not avallatle for public use).

5. J. L. Botts, R. J. Raridon, and D. A. Costanzo, Density, Acidity and Conductivity Measurements of Urany 1 Nitrate-Nitric Acid Solutions, ORNL-5260 (in preparation).

6. G. W. Weber et a1., Properties of Carbonized and Converted UraniumLoaded Weak-Acid Resiris, ORNL-5201 (February 1977). 
7. R. D. Spence and P. A. Haas, Tests of a Higgins Column for EngineeringScale Resin Loading of Uranium, ORNL/Tht 5973 (in preparation).

8. J. P. Drago and P. A. Haas, Drying of Uranium-Loaded Cation-Exchange Resin with Microwave Heating, ORN/TM-5508 (November 1976).

9. J. P. Drago and P. A. Haas, Design and Test of a The rmosiphon Evaporator for Acid-Deficlent Uranyl Nitrate, ORNL/TM-5518 (November 1976).

10. B. C. Finney and P. A. Haas, Sol-Gel Process -- Englneering-Scale Demonstration of the Preparation of "gh-Density $\mathrm{UO}_{2}$ Mcrospheres, ORNL-4802 (November 1972).

11. J. W. Snider, The Design of Engineering-Scale SOLEX Equipment, ORNL-4256 (Apri1 1969).

12. C. C. Haws, B. C. Finney, and W. D. Bond, Engineering-Scale Demonstration of the Sol-Gal Process: Preparation of $100 \mathrm{~kg}$ of Th02-U02 Microspheres at the Rate of $10 \mathrm{~kg} /$ Day, ORNL-4544 (May 1971).

13. A. J. Weinbergez, Oak Ridge National Laboratory, personal communication, November 1975 . 
12. APPENDIXES 
12.1 Appendix A: Descriptions of In-line $\mathrm{pH}$ and Density Instrumentation for ADUN Solutions

Three In-11ne pH instrumentation systems were purchased as follows:

(1) Beckman Instruments, Inc. (Vendor)

(a) Digital pH meter, Model 3500

Range: 0 to $14 \mathrm{pH}$

Temperature compensation: 0 to $100^{\circ} \mathrm{C}$

(b) pH Analyzer Model $940 \mathrm{~A}$

Lower range ifmit: 0 to $12 \mathrm{pH}$ continuous adjustable

Span: Sel 2, 16 , or $14 \mathrm{pH}$

Temperature compensation: 0 to $50^{\circ} \mathrm{C}$

Recorder output: $4-20 \mathrm{~m}$

Scale: 0 to 5

(c) pH Electrode Assembly Series 300

Cat. 300-2-0-17-1-1-1-0

(2) Foxboro Company (Vendor)

(a) $\mathrm{pH}$ electrode flow through holder

Series $8.5 \mathrm{C}-2$ with electrodes

(b) $\mathrm{pH}$ to current converter, 699-FN-2J

Range: 2 to $14 \mathrm{pH}$

Operating range: 0 to $5 \mathrm{pH}$

Temperature compensation: automatic 0 to $50^{\circ} \mathrm{C}$

Recorder output: 4 to $20 \mathrm{mh}$

(3) Leeds and Northrup Company (Vendor)

(a) $\mathrm{pH}$ electrodes, transmitter and mounting assembly Model 7773-1-1-02-2

(b) $\mathrm{pH}$ recelver, 7073-11-03-402-6-20

Range: 0 to $4 \mathrm{pH}$

Output: 4 to $20 \mathrm{~mA}$

The in-1ine density instrumentation was purchased as follows:

Automation Products, Inc. (Vendor)

Density Specific Gravity Instrumentation "Dynatrol"

Density-SFG Control Type CL-10HY Combo Series 300G

Process connection: $1 / 2$ in. NPT

Material: Stainless steel

Specific gravity range and access: 1 to $1.5 \pm 0.1 \%$

Plow rate: 1 to 511 ters/min

Output: 4 to $20 \mathrm{~mA}$ 


\subsection{Appendix B: Scale-up for Commercial Recycle Plants}

Full-scale comercial reprocessing and refabrication oi itGR fuels would require capacities of about $1.2 \mathrm{~kg} / \mathrm{hr}$ or $30 \mathrm{~kg} / \mathrm{day}$ for both ${ }^{23 j_{\mathrm{i}}}$ and recycle ${ }^{235} \mathrm{U}$. This caparity was demonstrated during tests cí the Higgins continuous loading contactor (Sect. 3.3). The purp.sse of this appeidix is to suggest a flowsheet for the scale-up using batch loading contactors.

The minimum cycle duration for a batch uranium luading contactor is the sum of three times, as follows:

1. The time required to pass enough uranium (ADUN solution) through the resin to complete about $80 \%$ of the uranium loading. Both the ADUN uranium concentration and the ADLN flow rate are limited if the resin is to be fluidized. The diameter or cross section for flow is limited to permit control of criticality. Operation under conditions which pack the resin against the exit screen are undesirable because refluidisation is difficult.

2. The time to complete the last 10 to $20 \%$ of uranium loading. This time, which is $2 \mathrm{hr}$, cannot be significantly shortened. Although this time is almost independent of the batch size, the ADUN must be at a favorable acid deficiency.

3. The time required to discharge the uranium-loaded resin, charge fresh resin, etc. During this period, the contactor is "off-stream" and does not require ADUN flow.

While operation to discharge one resin batch containing $4 \mathrm{~kg}$ of uranium every $3 \mathrm{hr}$ is not impossible, a cycle with $8 \mathrm{~kg}$ every $6 \mathrm{hr}$ appears much more practical. Two pairs (a cotal of four) of restn loajing 
contactors of the size tested (5 in. ID, $4 \mathrm{~kg}$ of uranium per batch) could be operated alternately with one pair "on-stream" at a time with a controlled ADUN flow to each contactor. The same cycle could be used with two critically safe contacturs (slab, annulus) of twice the crosssectional zrea of the 5-in.-ID contactors and $8 \mathrm{~kg}$ of uranium per batch. The 6-hr cycle time allows a well-controlled approach at a moderate rate to the preferred ADUN concentrations. A 3-hr cycle time allows Hitle time for correction and may require overlapping cycles.

\subsection{Appendix C: Operating Schedule for a 4-hr Cycle}

The process operations for resin loading can be carried out in many different sequences. The example shown as Table 7 would allow alternate operation of two loading contactors to discharge a batch of loaded resin ( $4 \mathrm{~kg}$ of uranium) every $4 \mathrm{hr}$. For a smaller dally capacity, the addition of uranyl nitrat: feed, the return of wash water, and the resulting $\therefore$ DUN volume adfustments might be done between resin loading operations in order to minimize the process changes during resin loading.

\subsection{Appendix D: Taiulated Ris Conditions and Results}

Some run conditions and data for cifferent resin types and batch numbers are tabulated (Table 8). The size and shape separation treatments of feed resin did not have any significant effects on the uranium loading results and are therefore not included. The results of end-ofcampaign procedures and other process variations are shown, alung with results for the most $\$$ imilar run without such variations ('able 9). 
Table 7. Schedule and flow rates for amine extraction process

\begin{tabular}{|c|c|}
\hline $\begin{array}{l}\text { Time } \\
\text { (min) }\end{array}$ & Procuss criteria or operation \\
\hline 0 & Start ADUN flow to resin loading, 1.7 liters/mir. \\
\hline 3 & Start UNH feed flow, 0.5 eq/min. \\
\hline 6 & Start scrub flows to amine regeneration, 0.1 liter/min. \\
\hline 8 & Start solvent flow to amine regeneration, $0.8 \mathrm{liter} / \mathrm{min}$. \\
\hline 10 & Start caustic flow to amine regeneration, $0.16 \mathrm{lite} / \mathrm{min}$. \\
\hline 15 & $\begin{array}{l}\text { Start steam to evaporator at } 0.6-1 \text { iter/min condensate } \\
\text { rate. }\end{array}$ \\
\hline 40 to 60 & $\begin{array}{l}\text { Receive approximately } 30 \text { liters of transfer and wash } \\
\text { solution from rasin dryer. }\end{array}$ \\
\hline$\sim 71$ & Stop UNH feed (approximately $4 \mathrm{~kg}$ of uranium added). \\
\hline$\because 90$ & $\begin{array}{l}\text { When resin exit } \mathrm{pH} \geq 1.6 \text {, increase resin loading flow to } \\
5 \text { liters/min. }\end{array}$ \\
\hline$\sim_{120}$ & $\begin{array}{l}\text { Receive overflow from charging new batch of feed resin } \\
\text { to other resin loading contactor ( } \sim_{1} ? \text { liters). }\end{array}$ \\
\hline च 150 & $\begin{array}{l}\text { When ADUN concentration or volume reaches preselected } \\
\text { value, turn off evaporator. }\end{array}$ \\
\hline $\begin{array}{l}\sim 156 \\
\sim 158 \\
\sim 160\end{array}$ & $\begin{array}{l}\text { When } \mathrm{pH} \text { of } A D U N \text { from surge tank has } \mathrm{pH} \geq 3.2 \text {, shut of } \mathrm{f} \\
\text { amine regeneration system in reverse order (caustic, } \\
\text { solvent, scrub). }\end{array}$ \\
\hline 235 & $\begin{array}{l}\text { Shut off resin loading contactor (check pH of ADUN to } \\
\text { confirm loading). }\end{array}$ \\
\hline
\end{tabular}


Table 8. Sore resin loading results with refereace batch loading flowsheet procedi:res

Equipment: engineering-seale resin loading, system

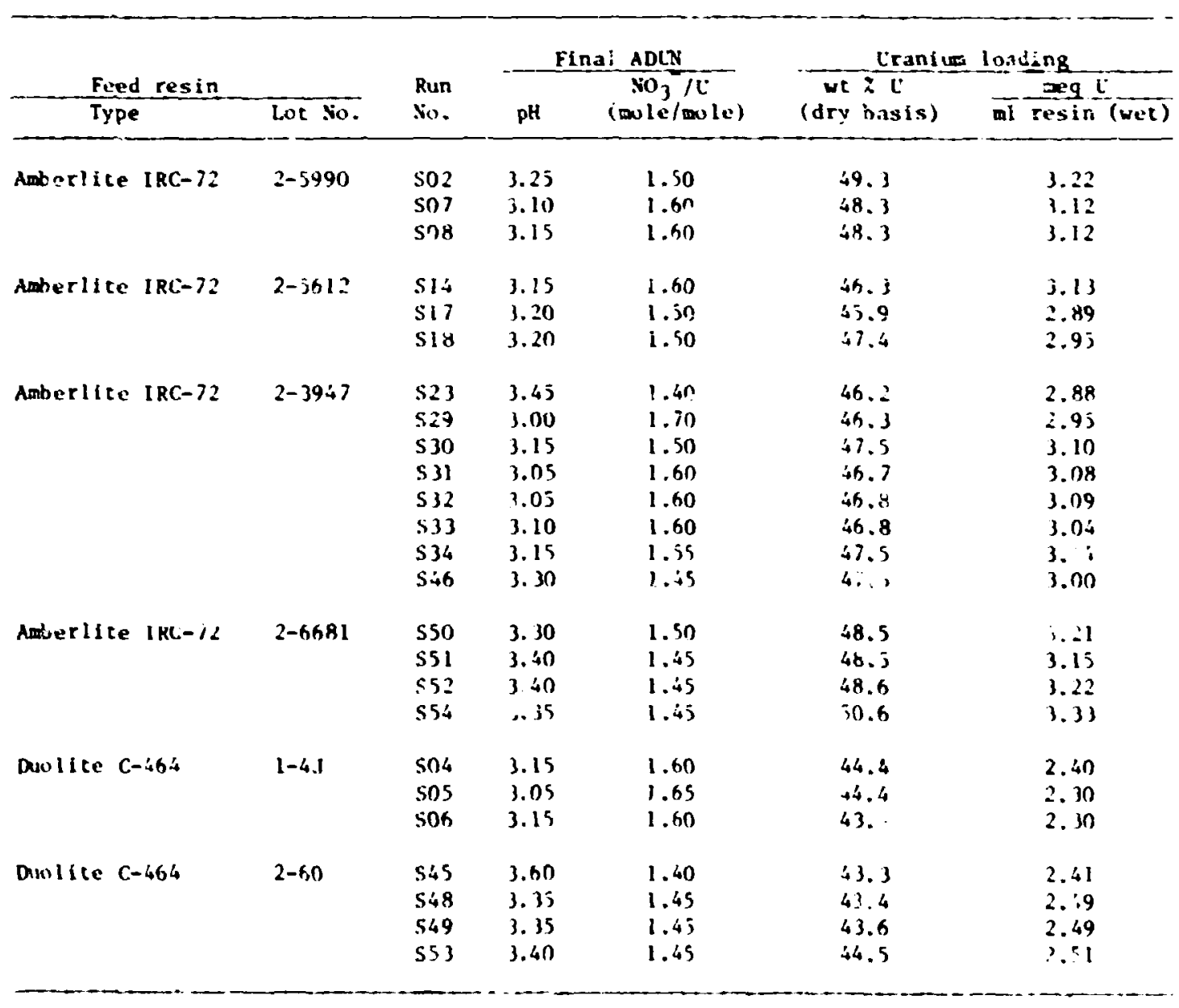




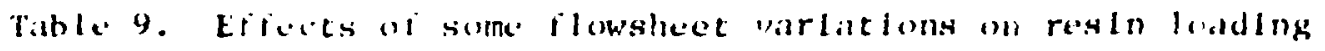

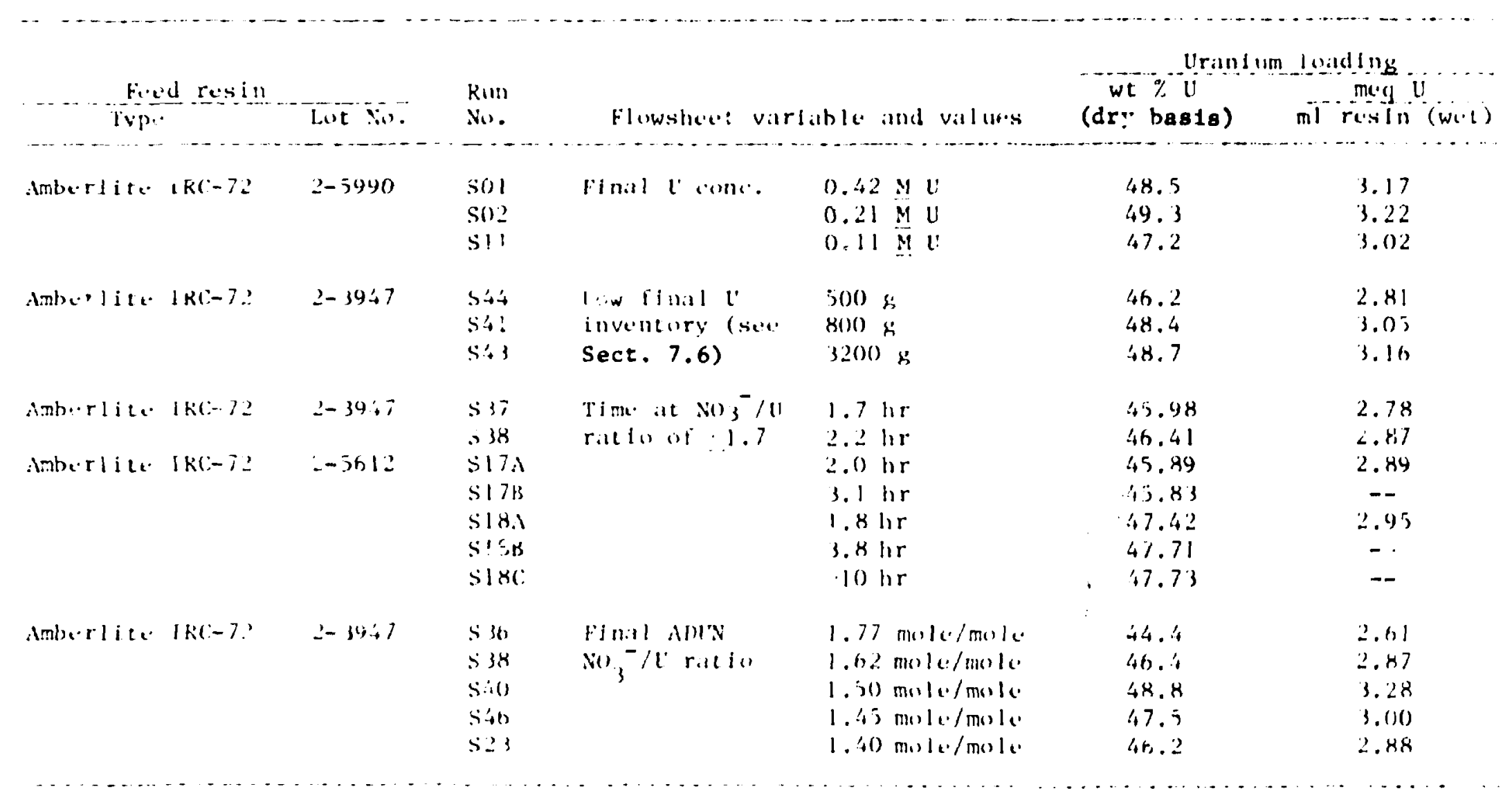

